\title{
SEEKING JUDICIAL LEGITIMATION IN THE COLD WAR: U.S. FOREIGN POLICY AND THE WORLD COURT, 1948-1962
}

\section{Michla Pomerance}

\section{INTRODUCTION}

In one of the twists of irony of which recent history has been replete, U.S. reassessment of its attitude to the International Court of Justice, sparked by the perceived unjustified judicial intrusion into the Cold War in the Nicaragua case, was launched just as the Cold War itself was winding down, to be replaced by a period of U.S. supremacy in a unipolar world. Reflecting the new global configuration of forces, the United Nations as a whole was becoming a forum more friendly to U.S. interests than at any time since the halcyon days of the Organization's infancy. The harmony of the U.S.-Court relationship in the early Cold War period now seemed to many a more relevant model for use in the ongoing reassessment than the state of acridity to which the relationship had fallen of late.

To critics of the official U.S. reaction to Nicaragua, the early U.S.-Court nexus had never lost relevance. Of particular importance was the succession of cases in which the United States had found judicial legitimation useful in Cold War-linked "organizational" skirmishes with the Soviet Union. However, the lessons to be derived from these cases varied, depending on the perspective of the critics. Some considered that the United States had attempted cynically to utilize the Court as yet another arena for pressuring the rival superpower and scoring propaganda points. They therefore faulted the Reagan Administration for continuing to adhere to this cynical tradition. Others, of the Moynihan persuasion, seeing in the earlier cases a significant measure of U.S. dedication to international law and the Court, berated the Administration for abandoning the earlier tradition because of unfounded fears that the cards in the Court were now stacked against U.S. interests and because of ignorance of the benefits of the rule of law for the long-term interests of the United States. ${ }^{1}$ Both conclusions were oversimplified, in part perhaps because neither set of critics bothered to examine the early record closely. Yet, unless properly assessed, that record could surely yield little that was useful for the purposes of setting future policy toward the Court.

Michla Pomerance teaches International Law and American Foreign Poicy in the Department of International Relations at Hebrew University of Jerusalem. She received her M.A. in 1961 and her Ph.D. in 1968 from Columbia University. Professor Pomerance is a former fellow of the Woodrow Wilson International Center for Scholars, Washington, D.C.

Acknowledgements: The author wishes to thank the U.S. Institute of Peace and the National Endowment for the Humanities for generous grants that made possible the research for this article

1. See, e.g., Daniel Patrick MoYnihan, ON the Law of Nations (1990). 
For obvious reasons, judicial legitimation in the Cold War could be furnished primarily by means of the Court's advisory, rather than contentious, jurisdiction. Straight-out adjudication required consent, and apart from the "fluke" of the Corfu Channel case, ${ }^{2}$ this would not be forthcoming in those years, from either the Soviet Union or any of its satellites. U.S. attempts to have aerial incidents involving the Soviet bloc inscribed on the Court's agenda were made several times during the decade of the 1950s. These attempts were merely predictably futile gestures designed, as Jessup notes, "to reveal this country's devotion to the ideal of judicial settlement of international disputes and to expose the undeviating refusal by our adversaries to accept any third-party settlement of disputes to which they were parties." ${ }^{3}$ However, the advisory competence was another matter. The absence of Soviet consent could still defeat a request for an advisory opinion in the Security Council ${ }^{4}$ but not

2. Albania appeared before the Court without contesting jurisdiction, and the Court was therefore able to base its jurisdiction on that state's implied consent in the course of the proceedings. See 1948 I.C.J. REP. 15. See also the discussion of the forum prorogatum principle in 1 Shabtai Rosenne, THE LAW AND PRActice of THE INTERNATIONAL COURT 344-63 (1965).

3. Philip C. Jessup, The Development of a United States Approach Toward the International Court of Justice, 5 VAND. J. TRANSNAT'L L. 6 (1971). For a description of the cases, see id. at 6-11.

In 1960, after the Soviet Union complained in the Security Council of U.S. violation of Soviet aerial space over the Barents Sea, Ambassador Lodge introduced a resolution, U.N. Doc. $S / 4409$ (1960), to have the incident clarified by a fact-finding commission or the International Court of Justice, but the resolution was defeated by a Soviet veto. Jessup, supra this note, at 10; U.N. SCOR, 15th Yr., 881st-883rd mtgs. (July 25-26, 1960).

It may be noted that during several crises in the early years of the Cold War, the possibility of utilizing the Court by means of joint reference was considered by the State Department. On the Berlin blockade, see e.g., 2 FOREIGN RELATIONS OF THE U.S. 1948, at 954, 957. In the course of the Korean armistice talks at Panmunjom, the suggestion to refer to the International Court the issue of voluntary repatriation of prisoners of war-the main sticking point in the negotiations-was raised in high-level discussions at the State Department on January 31, 1952. Whether the Court's contentious or advisory jurisdiction was contemplated is not clear from the record. In any case, it was decided that "the action was not desirable on the grounds that public opinion value was doubtful and it would appear to build the issue up with decreased possibility of resolution." 15 FOREIGN RELATIONS OF THE U.S. 1952-1954, at 33-34.

4. The matter of the vote required for Security Council requests is not explicitly govemed by any Charter text. In the early years of the United Nations, there was some debate regarding the "substantive" or "procedural" nature of votes to request advisory opinions, but in practice the Security Council deemed the veto applicable.

In the Namibia case, South Africa contended that the requesting resolution (S.C. Res. 284) was invalid because, though it was "nonprocedural" in nature, two permanent members had abstained; and Article 27(3) required the "concurring votes" of all the permanent Council members on such questions. The Court did not find it necessary to pronounce itself on this 
in the General Assembly, where recourse to the Court could be decided by a simple or two-thirds majority. ${ }^{5}$ Thus, until 1960-1962, the Assembly could, at times, be a convenient forum both for providing political legitimation regarding Cold War issues and for summoning additional judicial legitimation. Thereafter, the picture was to change on both scores.

Even during the heyday of U.S. influence in the General Assembly and U.S. satisfaction with the Court, the United States exhibited no consistent pattern of seeking to involve the Court, whenever possible, in Cold War controversies. Its attitude was neither excessively cynical nor greatly idealistic, but, overall, pragmatic. Sometimes the United States initiated the march to the Court; at other times it unenthusiastically acquiesced; and, occasionally, it successfully resisted the initiatives of others. U.S. motives in the matter were varied, and hardly one-dimensional. Short-range calculations vied with longer-range considerations, not always very felicitously either from the standpoint of U.S. interests or from that of the prestige and status of the Court. This was demonstrated most sharply in the Expenses advisory opinion of 1962, where the United States, in the longer perspective, reaped a Pyrrhic victory. Its view of the powers of the General Assembly was endorsed by the Court at the very moment when the balance of forces within the Assembly was beginning to tilt against the United States. Before long, the United States, rather than the Soviet Union, would wish to default on payments decreed by "automatic majorities" in the Assembly.

In 1962, too, the signs of the changing times were felt in the Security Council, where a curious reversal of roles occurred. Recognizing that "two could play the same game," Cuba and its Soviet patron pressed for judicial clarification of the legality of a series of anti-Cuban decisions of the OAS-a suggestion strenuously objected to by the United States on the grounds that

question since, in any case, it considered that the voluntary abstention of a permanent member did not prevent the adoption of non-procedural resolutions. 1971 I.C.J. REP. 22. However, compare the questions of Judges Jiménez de Aréchaga and Morozov to the U.S. representative, Namibia case, 1971 I.C.J. Pleadings 2, at 507-08, which were designed to elicit clarification on the applicability of the veto to requests for advisory opinions.

For the view within the State Department that requests for advisory opinions were subject to veto, see 2 FOREIGN RELATIONS OF THE U.S. 1951, at 353, 404. See also the statement of Representative Warren Austin 1 FOREIGN RELATIONS OF THE U.S. 1948, at 222, and the explanation of the U.S. Delegation's stand, offered by Eric Stein, id. at 252 ("[S]ince the Security Council would and should abide or act in accordance with a Court opinion the request for such opinion affects the substance of and the eventual action on the matter.").

5. There was no across-the-board ruling on the vote required for General Assembly requests. The issue has been decided ad hoc and has sometimes been dependent on the nature of the resolutions to which the proposed request for an advisory opinion was linked. For an early illustration of this trend, see MICHLA POMERANCE, THE ADVISORY FUNCTION OF THE INTERNATIONAL COURT IN THE LEAGUE AND U.N. ERAS 239 n.332 (1973). 
the matter was entirely "political" and that the Court should not be dragged into the Cold War propaganda struggle. In essence, the Cuban episode was merely a preview of the drama to be played out more than two decades later in the Nicaragua case.

In the present article it is proposed to scrutinize more closely how U.S. foreign policy makers approached the idea of judicial legitimation in respect to Cold War matters during the critical period of 1948-1962. The four Cold War requests-in the Admission, Competence, Peace Treaties, and Expenses cases-necessarily form the primary focus. ${ }^{6}$ In addition, abortive requests relating, respectively, to exit visas for Soviet wives, the aftermath of the Competence case, and the anti-Cuban OAS resolutions, furnish a complementary prism from which to gain a more accurate impression of the American tradition vis-à-vis the World Court.

\section{THE "COLD WAR" REQUESTS}

\section{A. Admission and Competence}

Of the four requests related to the Cold War, two arose in the context of the admissions deadlock that plagued the United Nations during its early years. Both of these requests involved interpretations of Article 4 of the Charter, specifically Article 4(1) in the Admission case and Article $4(2)$ in the Competence case. ${ }^{7}$ The United States did not initiate or co-sponsor either request. But whereas it supported the first without expressing any reservation, its attitude to the second was highly ambivalent. U.S. consent was only reluctantly given against a background of internal divisions in the U.S. Delegation to the United Nations and the U.S. State Department.

By the end of 1947, the bipolar division of the world had led to an impasse over the admission of new members to the Organization. Each bloc, employing the weapon at its disposal, had excluded members of the other. Western-led majorities in the Assembly blocked the Soviet-sponsored applications of

6. The cases involving spillover from the Cold War into the international secretariats-such as the U.N. Administrative Tribunal and UNESCO cases-will be considered in a separate article.

7. The text of Article 4 is as follows:

1. Membership in the United Nations is open to all other peace-loving states which accept the obligations contained in the present Charter and, in the judgment of the Organization, are able and willing to carry out these obligations.

2. The admission of any such state to membership in the United Nations will be effected by a decision of the General Assembly upon the recommendation of the Security Council. 
Rumania, Bulgaria, Hungary, Albania, and Mongolia, while Soviet vetoes in the Security Council barred the admission of such non-communist states as Finland, Italy, Portugal, Ireland, Ceylon, Austria, and Transjordan. The reasons adduced for opposition to the several candidacies were varied. ${ }^{8}$ Some were broadly related to the criteria set forth in Article 4(1) of the Charter ("peace-loving," "able and willing to carry out" Charter obligations), but others clearly were not. Among the latter was the stand finally taken by the Soviet Union regarding five former enemy states: Italy and Finland could be admitted only if Bulgaria, Hungary, and Rumania were admitted simultaneously. The suggestion for such en bloc admissions was strongly opposed by the United States and other Western states. True, in August 1946, the United States had itself proposed a "package" of admissions," but after the proposal had encountered Soviet and Australian opposition, the United States had shifted its attitude and insisted that each candidacy be considered separately on its merits.

The idea of having the legality of the Soviet "package deal" approach judicially tested was not pushed by the United States. It was incorporated in a Belgian draft resolution of November $7,1947,{ }^{10}$ and even many sympathetic states were skeptical of its utility. " Indeed, given the vigorous

8. See LELAND M. GOODRICH \& EdVARD HAMBro, CHARTER OF THE UNTTED Nations: COMMENTARY AND DOCUMENTS, 128-30 (2d ed. 1949); U.N. SCOR, 1st Yr., 2d Ser., Supp. No. 4 (1946); id., 2d Yr., Spec. Supp. No. 3 (1947). Grounds for opposition included a state's neutrality in the past war; the absence of diplomatic relations between the objecting and applicant states; and, in the case of former enemy states, the absence of peace treaties.

9. U.N. SCOR, 1st Yr., 54th mtg. (Aug. 28, 1946), at 42.

10. U.N. Doc. A/C. 1/242 (1947). For the Belgian explanation of this draft resolution, see U.N. GAOR 1st Comm., 2d Sess., 98th mtg. (Nov. 7, 1947), at 342. The question asked was:

Is a Member of the United Nations which is called upon, in virtue of Article 4 of the Charter, to pronounce itself by its vote, either in the Security Council or in the General Assembly, on the admission of a State to membership in the United Nations, juridically entitled to make its consent to the admission dependent on conditions not expressly provided by paragraph 1 of the said Article? In particular, can such a Member, while it recognizes the conditions set forth in that provision to be fulfilled by the State concerned, subject its affirmative vote to the additional condition that other States be admitted to membership in the United Nations together with that State?

11. For example, the United Kingdom representative stated that, although the projected opinion would not solve the present difficulties, he would vote for requesting it because, under Article 96 of the Charter, the Court could be consulted in cases of conflicting interpretations of Charter provisions. U.N. GAOR 1st Comm., 2d Sess., 101st mtg. (Nov. 8, 1947), at 378. And see the statements of Australia, id., 99th mtg. (Nov. 7, 1947), at 351; U.N. GAOR, 2d Sess., 117th plen. mtg. (Nov. 17, 1947) at 1053-55. The Greek representative cited as grounds for his support the desirability of more frequent use of the Court. U.N. GAOR Ist Comm., 
Soviet objections to recourse to the Court, the admission impasse was not likely to be affected by any Court pronouncement. ${ }^{12}$ Even the propaganda value of the projected opinion could only be limited, at best. The conditions stated in Article 4(1) of the Charter are so broad that, even if deemed exhaustive - as, in fact, the Court majority subsequently deemed them to be-the Soviet Union would experience no great difficulty in confining itself to the stated criteria in order to bar the admission of any applicant state. ${ }^{13}$ Moreover, no state is obliged to explain its vote, and the entire matter boiled down to a question of motives and good faith, which are not subject to judicial control. ${ }^{14}$

2d Sess., 101st mtg. (Nov. 8, 1947), at 382. See generally, POMERANCE, supra note 5, at 91-92. The vote on the draft resolution in the First Committee (26 to 13, with 16 abstentions) reflected the widespread hesitation. In Plenary, the vote was more overwhelmingly in favor: $\mathbf{4 0}$ to 8 , with 2 abstentions.

12. The Soviets objected, interalia, to the "political" nature of the request and to giving the Court the task of interpreting the Charter in the abstract. The terms of Article 4 were said to be sufficiently clear; the grounds for refusing certain states' admission had been "political," and every state had an equal right to be guided by political motives. See, e.g., U.N. GAOR, 2d Sess., 117th plen. mtg. (Nov. 17, 1947), at 1048, 1050-51; U.N. GAOR 1st Comm., 2d Sess., 99th mtg. (Nov. 7, 1947), at 360.

13. At least at one point in the pre-request debate, the Soviet delegate conceded the exhaustive nature of the requirements of Article 4(1) and stated that his government merely doubted the "peace-loving" nature of the states concerned. U.N. GAOR 2d Sess., 117th plen. mtg. (Nov. 17, 1947), at 1048.

14. Oliver J. Lissitzyn, The INTERNATIONAl COURT OF JUSTICE: ITS ROle IN THE maintenance of International Peace and Security 91 (1951).

Both the majority and minority opinions were predicated on the exercise of good faith. In the majority opinion, the Court determined that the conditions in Article 4(1) were exhaustive. It held that a U.N. member "cannot, while it recognizes the conditions set forth in that provision to be fulfilled by the State concerned, subject its affirmative vote to the additional condition that other States be admitted to membership ... together with that State." 1948 I.C.J. REP. 65. However, the Court interpreted the Assembly's request to relate only to "the statements made by a Member concerning the vote it proposes to give." It did not relate to a state's "actual vote," since "the reasons which, in the mind of a Member, may prompt its vote" were matters of "a mental process," which are "obviously subject to no control." Id. at 60 . Moreover, the Court emphasized that "Article 4 does not forbid the taking into account of any factor which it is possible reasonably and in good faith to connect with the conditions laid down in that Article." And the Court added that "no relevant political factor-that is to say, none connected with the conditions of admission-is excluded." Id at 63. On the other hand, the joint dissenting opinion held that the Assembly's question related not only to a U.N. member's statements, but also to the member's vote and the reasons underlying it, and that the conditions of Article 4(1) were necessary but not sufficient. Id. at 82-93. But, in their view, while a U.N. member is "legally entitled to make its consent to the admission dependent on any political considerations which seem to it to be relevant," in exercising this power the member "is legally bound to have regard to the principle of good faith, to give effect to the Purposes and Principles of the United Nations ... . Id. at 92 . "To act in good faith," they said, was "an overriding legal 
Thus, the opinion, quite predictably, would be one which would "provide a cloak for any kind of action."15 In the aftermath of the opinion, there was some appreciation of this fact in the State Department and the U.S. Delegation to the United Nations, ${ }^{16}$ but the record indicates no comparable awareness on the part of U.S. decision-makers and representatives during the pre-request phase. The United States apparently voted for the Belgian draft resolution, and it made no qualifying explanatory statement. ${ }^{17}$

On the surface, the General Assembly request for an advisory opinion two years later, in the Competence case, was a natural sequel to the Admission opinion, a second sally in a concerted Western campaign against Soviet obstructionism in the United Nations. If salvation could not be provided by Article 4(1), however interpreted, the logical next step was to seek it in Article $4(2)$, reinterpreted so as to avoid the obstacle of the veto. In point of fact, no such grand design underlay the decision to consult the Court in this instance. From the pre-request history and the Pleadings in the case, it appears that the decision resulted from a one-man initiative, which was greeted by a notable lack of enthusiasm on the part of most Western states. Some of these States voted to oppose it, and the United States came very close to joining the opposing or abstaining camps.

The Argentine representative in the United Nations, Dr. Arce, had long espoused a rather controversial interpretation of Article 4(2), the crux (and better-known part) of which was that the word "recommendation" in that

obligation resting upon every Member of the United Nations." Id. at 91. See also the dissenting opinions of Judges Zoricic and Krylov, id. at 94-115, and their emphasis on the good faith obligation, id. at 103, 115; and see the separate opinion of Judge Azevedo, id. at 73-81, in which he stated, inter alia, that "elements of expediency, manifest or hidden, can always be considered when reasonable use is made of the wide possibilities opened by Article 4." Id. at 81. Little wonder, then, that the French representative in the General Assembly later concluded that the difference between majority and minority opinions was merely semantic and was "largely based on a quibble." U.N. GAOR, 4th Sess., 251st plen. mtg. (Nov. 22, 1949), at 316; see also U.N. GAOR Ad Hoc Political Comm., 3d Sess., 1st Part, 11th mtg. (Nov. 24, 1948), at 117 .

15. SiR HERSCH LAUTERPACHT, THE DEVELOPMENT OF INTERNATIONAL LAW BY THE INTERNATIONAL COURT 150 (1958).

16. See, e.g., 2 FOREIGN RELATIONS OF THE U.S. 1951, at 347-50, 361, 363, 370, 380, $389,392,395,403$; 3 FOREIGN RELATIONS OF THE U.S. 1952-54, at 829-30, 833-34. See also the discussion of the aftermath of the Competence case, infra part III.B.

17. For discussions in the First Committee on the issue, see U.N. GAOR 1st Comm., 2d Sess., 98th-103d mtgs. (Nov. 7-10, 1947); U.N. GAOR, 2d Sess., 117th-1 18th plen. mtgs. (Nov. 17, 1947). For votes, see U.N. GAOR 1st Comm., 2d Sess., 103rd mtg. (Nov. 10, 1947), at 397; U.N. GAOR, 2d Sess., 118th plen. mtg. (Nov. 17, 1947), at 1078. 
provision did not necessarily mean "favorable recommendation."18 Just as the Assembly could proceed to deny a state admission after a favorable Security Council recommendation, it could reject an unfovorable Security Council recommendation and decide to admit a state. For this part of his thesis, Dr. Arce could find few buyers. But there was a second, alternative, part to the thesis, and it was gaining wider support, especially among some Latin American states. The veto, he argued, was inapplicable to admission questions, and the Assembly therefore was free to consider as favorable a recommendation which received the affirmative vote of any seven Council members. ${ }^{19}$

By the fourth General Assembly session, the Argentine representative had despaired of getting the Assembly to endorse the substance of his thesis. ${ }^{20}$ The United States, the other permanent Security Council members, and a majority of the Assembly were arrayed together with the Soviet Union against it. But Dr. Arce could count on a large "sympathy vote" for his new initiative to have the thesis judicially tested..$^{21}$ Appreciation for Argentina's admirable motives and the desire to give Argentina its day in Court seemed to be the most compelling reasons prompting states to support the resolution requesting an advisory opinion. ${ }^{22}$

18. As he explained at one point, "recommendation" no more implies "favorable recommendation" than "woman" implies "pretty woman." Id. at 1072. The Argentine thesis was premised primarily on the travaux préparatoires, and especially one document of the Advisory Committee of Jurists at the San Francisco conference in 1945. Id.

19. These two alternative approaches are more fully set forth in the Argentine Written Statement submitted to the Court. 1950 I.C.J. Pleadings 123-48.

20. In the third session, for example, an Argentine draft resolution (U.N. Doc. A/AC.24/15 [1948]) was withdrawn after it became apparent that it would be defeated. U.N. GAOR Ad Hoc Political Comm., 3d Sess., 1st Part, 14th mtg. (Nov. 26, 1948), at 156.

21. U.N. Doc. A/AC.31/L.18 (1949). Earlier, Argentina had been among states expressing doubts concerning the Court's competence to interpret the Charter. See, e.g., in the pre-request phase of the Admission case, U.N. GAOR 1st Comm., 2d Sess., 100th mtg. (Nov. 8, 1947), at 370; U.N. GAOR, 2d Sess., 118th plen. mtg. at 1071. (Nevertheless, Argentina voted for the request.) As late as the third Assembly session, the Argentine representative rejected a suggestion that the interpretation of Article 4(2) be referred to the Court, on the ground that the Court would probably consider itself incompetent to deal with it. U.N. GAOR Ad Hoc Political Comm., 3d Sess., 1st Part, 11th mtg. (Nov. 24, 1948), at 156.

22. POMERANCE, supra note 5, at 104-07. The resolution was reformulated, no longer focusing on one document in the travauxpréparatoiresof the U.N. Charter, as in the original Argentine draft resolution. A new text, formulated jointly by Argentina and Belgium, was substituted. U.N. Doc. A/AC.31/L.20 (1949). The question now was:

Can the admission of a State to membership in the United Nations, pursuant to Article 4, paragraph 2, of the Charter, be effected by a decision of the General Assembly when the Security Council has made no recommendation for admission by reason of the candidate failing to obtain the requisite majority or of the negative vote of a permanent member upon a resolution so to recommend? 
The United States did not participate in the pre-request Assembly debate, presumably because the U.S. Delegation experienced considerable difficulty in determining its stance. Before the formal Argentine draft resolution was submitted, a U.S. Delegation position paper of October 22, 1949 had recommended firmly that "the United States should oppose any proposal embodying or giving application to the Arce view that the General Assembly can admit an applicant which has not received a favorable recommendation from the Security Council."23 Notwithstanding its desire to break the admissions deadlock, the United States did not wish to weaken the veto in this manner. Furthermore, the Delegation was to "strongly discourage in its conversations" the idea of requesting an advisory opinion with respect to the Argentine thesis "on the ground that the question involves no serious legal difficulties." If the proposal nevertheless came to a vote, the Delegation "should preferably abstain or vote adversely." ${ }^{12}$

U.S. informal efforts at dissuasion having failed, the U.S. Delegation was convened on November 1, 1949 to consider how to vote on the Argentine draft resolution. Some members still insisted that abstention or opposition was the wiser course and that the draft resolution represented an improper

Insofar as the Assembly desired a judicial answer to all parts of the Argentine thesis, the formulation of the question was defective. For while it required a reply as to the contention that an unfavorable Council recommendation might yet lead to admission by the Assembly, it allowed the Court to avoid answering directly the question-avowedly the more important-whether, despite the veto, a recommendation might be considered by either the Security Council or the General Assembly as favorable. As framed, the question assumed the absence of a Security Council recommendation. See 1950 I.C.J. REP. 7. The Court's interpretation of the question accorded with that urged by the United States. Competence case, 1950 I.C.J. Pleadings 110-22. On the other hand, the Argentine Written Statement revolved entirely around the question of the veto. Id. at 123-48. Indeed, certain states-most notably, Lebanon-recommended the inclusion of more specific questions related to the effect of the veto on the admission of new members. U.N. GAOR Ad Hoc Political Comm., 4th Sess., 27th mtg. (Nov. 2, 1949), at 146. Most, however, appeared satisfied that the question, as framed, encompassed all the important elements of the problem.

Despite its narrow circumspection of the question, the Court did, in an oblique reference at the end of the opinion, indicate that the Assembly, at least, could not reverse to favorable a recommendation which the Security Council had deemed unfavorable. But the Court did not find it necessary to enter into the thicket of the applicability of Article 27(3) of the Charter to the admission of new states. Had the question of the veto been put unequivocally to the Court, it is conceivable that the Court would have considered itself incompetent to answer it. For it is by no means clear that the Assembly's authority to request advisory opinions extends to questions involving the voting procedure of a coordinate organ.

23. 2 FOREIGN RELATIONS OF THE U.S. 1949, at 303. See also 1 FOREIGN RELATIONS OF THE U.S. 1948, at 201.

24. 2 FOREIGN RELATIONS OF THE U.S. 1949, at 303. See also id. at 307; 5 FOREIGN RELATIONS OF THE U.S. 1949, at 240. 
"passing of the buck" to the Court. ${ }^{25}$ But Ambassador Austin was sympathetic to the Arce proposal, and the majority of the Delegation decided that, provided the draft resolution was appropriately reformulated, the United States should not oppose it. ${ }^{26}$ In this way, the United States would remain true to its tradition of encouraging more frequent recourse to the Court. ${ }^{27}$ Moreover, "the proposal presented an opportunity to take the Argentine proposition, which had been gaining favor over the years, 'out of the political forum' and on to a legal basis." ${ }^{28}$

In the end, the United States indeed voted for the proposal to request an advisory opinion. ${ }^{29}$ But it opposed the Arce thesis in the Pleadings before the Court. It also presented an interpretation of the question that allowed the Court to evade the second and more crucial part of the Argentine thesis, which bore on the applicability of the veto to admissions. ${ }^{30}$ That unresolved issue was to reemerge in later proposals and suggestions for requesting advisory opinions; and the United States helped ensure that all such suggestions would remain abortive. ${ }^{31}$

\section{B. Peace Treaties}

A very different posture was assumed by the United States with respect to another Cold War case of the early U.N. period. Just one month prior to the adoption of the Competence request, the United States initiated and co-sponsored in the General Assembly a proposal to seek the Court's advice in interpreting provisions of the peace treaties with Bulgaria, Hungary, and Rumania. Although unlikely to improve the root problem of the observance

25. These included Paul Taylor, Sam Kopper and Jack Tate, the State Department's Deputy Legal Adviser. Jessup, supra note 3, at 35-36.

26. See id. at 36, for the views of James Hyde, Philip Jessup, and Harley Notter. The Delegation did not wish to have the request refer to specific documents at San Francisco, as in the original Argentine draft resolution. Argentina would be free, of course, to present those documents as evidence before the Court.

27. Id. This was the argument presented forcefully by Notter, in particular.

28. 2 FOREIGN RELATIONS OF THE U.S. 1949, at 308 n.1.

29. U.N. GAOR Ad Hoc Political Comm., 4th Sess., 29th mtg. (Nov. 4, 1949), at 162; U.N. GAOR, 4th Sess., 252d plen. mtg. (Nov. 22, 1949), at 329. The vote in Committee was 37 to 9, with 8 abstentions; in Plenary, 42 to 9, with 6 abstentions.

30. Competence case, 1950 I.C.J. Pleadings 110-22. See supra note 22 and accompanying text. The first part of the Arce thesis was resoundingly rejected by the Court with a vote of 12 to 2, and the validity of past U.N. practice on admissions (requiring the Assembly to proceed only on the basis of a prior favorable Security Council recommendation) was thus confirmed. See 1950 I.C.J. REP. 4-10.

31. See the section on the aftermath of the Competence case, infra part III.B. 
of human rights in the three satellite states, recourse to the Court was viewed as a relatively cost-free exercise which might at least yield benefits in the East-West battle for world public opinion. It also was deemed by the United States to be preferable to the alternative then being promoted by certain Western states: direct investigatory and condemnatory action by the United Nations. Not calculated, however, in the U.S. cost-benefit analysis was the potential harm of an ineffective opinion to the prestige and standing of the International Court. At most, some members of the U.S. Delegation who shared the misgivings of several U.S. allies questioned the wisdom of submitting to the Court the last two of the four questions posed, but their view did not prevail.

The chain of events leading to the decision to involve the Court began in early 1949, when news of the arrest and trial of church leaders in Bulgaria and Hungary -and most prominently, Cardinal Mindszenty of Hungary ${ }^{32}$-reached the West and aroused widespread consternation and indignation. Writing to Secretary of State Dean Acheson, the U.S. Minister in Hungary reported that "public opinion in Hungary-and presumably elsewhere behind [the] Curtain-looks with anxiety for vigorous countermeasures not only in defense of US prestige but also as evidence [of] official US cognizance [of] cynical violation [of] human rights and proof of continued US interest in [the] welfare [of] peoples behind [the] Curtain. ${ }^{33}$ It seemed clear to him "that eventually the whole question of human rights in satellite countries must be forced into [the] UN Assembly and that Hungary, in light [of] recent developments . . . may well present [the] best point of attack. ${ }^{134}$ Ineffective protests, he warned, made the United States "appear feeble and irresolute"; and he recommended concerted Anglo-American efforts leading to U.N. investigations, and, if necessary, economic sanctions. Such a course would probably "exert restraining pressure on Czechoslovakia and Poland" as well. ${ }^{35}$

In response, Secretary Acheson conceded the broader implications of the Mindszenty case. There had been, he wrote, a general "intensification [of] measures of oppression" in the satellite states "as [an] instrument [of] Soviet indirect aggression." A forceful U.S. counter-offensive, utilizing but not focusing exclusively on the Mindszenty trial, was therefore warranted. ${ }^{36}$ At the outset, the United States merely issued diplomatic protests and public denunciations; but following the sentencing of Cardinal Mindszenty to life

32. Cardinal Mindszenty was arrested on December 27, 1948, and tried in early February 1949 for treason, conspiracy, and other crimes against the Hungarian state. He was sentenced to life imprisonment.

33. Telegram from Chapin, U.S. Minister in Hungary, to Secretary of State Dean Acheson, (Jan. 26, 1949) 5 FOREIGN RELATIONS OF THE U.S. 1949, at 223-24.

34. Id. at 223.

35. Id. at 224.

36. Circular telegram from Secretary of State Dean Acheson to Certain Diplomatic Missions (Jan. 31, 1949), id. at 225. 
imprisonment, the State Department concluded that further action was required. $^{37}$ After weighing two alternative approaches-invocation of the dispute-settlement provisions of the peace treaties with Bulgaria, Hungary, and Rumania ${ }^{38}$ against submission of the problem to a U.N. organ-the State Department inclined toward use of the first procedure, followed, or, if necessary, supplemented, by "some form of UN action." ${ }^{39}$ True, U.N. action had the advantage of providing "a forum for airing [the] entire subject of suppression of rights and Treaty violations with [the] opportunity for us [to] demonstrate [to] Eastern European peoples [the] cont [inue]d concern [of the] international community [with] their fate. ${ }^{140}$ But if the prospect of effective U.N. measures was "dubious," this mode of procedure might "be injurious to UN

37. Telegram from Secretary of State Dean Acheson to U.S. Embassy in U.K. (Feb. 12, 1949), id. at 227. Some U.S. embassies, in commenting on Acheson's circular telegram, had cautioned against measures which would merely accentuate Western ineffectiveness in Eastern Europe. Id. at 226. On the other hand, the U.S. Embassy in Moscow emphasized that any steps, including even sanctions, would probably be ineffective in the short term. They would not "deter the Soviet Union from consolidating its position in Eastern Europe" and "were not likely to cause any Communist regime to back down or reverse current policy." Id. Nevertheless, the prospects of victory in the long term militated against a policy of silence with respect to oppression by any Soviet bloc member. In words which ring truer today than when they were uttered, the U.S. Charge in the Soviet Union (Kohler) wrote:

[O]ur best traditions and our present interests require US to be constantly on offensive in political and psychological warfare fields in east Europe, retaining initiative in every possible way and stimulating resistance to Sovietization countries this area now in process. We cannot agree that even from humanitarian point of view we do these peoples a favor by remaining silent and inactive. ... Chances for these peoples to regain their freedom will in the long run depend largely on maintenance their love of liberty and fighting spirit. These will surely wither away unless kept exercised.

Id. at 231. The need for firmer U.S. action was spurred by the fact that on February 9, the House had adopted a concurrent resolution on the matter.

38. Under these provisions, disputes not otherwise settled by direct negotiations or by the three Allied Heads of Mission in the relevant capitals, were to be referred, at the request of either party, to a commission composed of one representative from each party and a third member selected by mutual agreement. Upon failure of the two parties to agree within a month on the appointment of the third member, either party might petition the U.N. Secretary-General to make the appointment. For the text of the provisions, see 1950 I.C.J. REP. 73.

39. Among the possible U.N. actions listed were "a reference to the Court, or a request for an advisory opinion from the Court." 5 FOREIGN RELATIONS OF THE U.S. 1949, at 229. Here, an advisory opinion on the merits of the issue of human rights observance was contemplated, not the questions eventually posed regarding the applicability of the dispute-settlement provisions of the peace treaties.

40. Telegram from U.S. Secretary of State Dean Acheson to Embassy in U.K. (Feb. $12,1949)$, id. at 229. 
organization." ${ }^{41}$ Moreover, any steps taken in the United Nations would have to reconcile the U.N. Charter provisions on human rights with the domestic jurisdiction clause (Article 2, paragraph 7). ${ }^{42}$ On the other hand, utilizing the treaty procedure would avoid this problem, though admittedly it "would preclude airing violations in Yugo[slavia], Czecho[slovakia] and Poland." It would place the case, "wherever brought," on "the soundest basis"; and even if it were necessary to involve the U.N. subsequently, it was better to first exhaust other methods, in line with Article 33 of the Charter. The peacetreaty procedure "might be protracted ... which, however, could serve [to] keep issues before world public opinion for [a] considerable period [of] time." Hungarian obstructionism would not be fatal, since the Secretary-General might nevertheless appoint the "third member" of the dispute-settlement commission, resulting in a "definite and binding decision" (as opposed to a mere Assembly recommendation). If Hungary remained defiant, the matter could then be brought before the Assembly on a firm legal foundation, thus keeping the issue alive.

In view of all these considerations, the State Department instructed the U.S. Mission at the United Nations not to "either encourage or discourage any del[egation] considering raising [the] matter in [the] UN. ${ }^{143}$

U.S. strategy in this matter was challenged initially from two quarters. The British hesitated, at first, to join the United States in activating the peace treaty machinery. They feared that trade negotiations with the Eastern bloc might be jeopardized; that the protracted negotiations would merely parade Western impotence and further harm Western prestige and influence; and that economic and diplomatic sanctions would be the inevitable (and from the British standpoint, undesirable) result. The alternative of condemnatory pronouncements proclaimed to the world at large would, in their view, be equally effective in indicting the human rights violations of the Balkan states. ${ }^{44}$ The State Department dismissed these arguments and contended, inter alia, that invocation of the treaty machinery was a "logical step" prior to U.N. involvement and would, more likely, forestall U.N. action in the interim; that "such course will usefully serve to continue pressure indirectly on the Soviet Union through the three satellites;" that "a definite binding decision," even if rejected by the satellites, would "be useful . . . as incontrovertible proof of treaty breach;" that the "mere fact that treaty machinery w[ou]ld consume [a] fairly extended period [of] time indicates [the] seriousness with which we view this matter"; that "our action would be heartening evidence of our

41. Id. at 228.

42. Id.

43. Id. at 229 n.4. For the full text of Acheson's telegram, see id. at 227-29.

44. Id. at 230, 235-36 nn.4-6. Action against Hungary alone was deemed particularly objectionable. Id. at 230 n.1. 
sustained interest in [the] fate of people of satellite countries and would serve to boost morale in cold war"; that public condemnatory pronouncements clearly would be ineffective, if only because of their past overuse; that the "principal British doubt" regarding future trade negotiations was unfounded because "the willingness of the satellites to trade" would be "more likely determined on a basis of strict economic advantage;" and that use of the treaty machinery, as opposed to an immediate appeal to the United Nations, would not lead inevitably to the imposition of economic or diplomatic sanctions. Rather, it would allow the maintenance of a "flexible position ... as to what if anything should be done thereafter." ${ }^{45}$

This last argument was directed also at the second source of opposition to the U.S. approach: the Latin American states. Their fury at the satellites' abuse of the Catholic Church led them to desire immediate U.N. condemnatory action, preferably by the Security Council. ${ }^{46} \mathrm{Cuba}$, in particular, was taking steps to move the issue to the Security Council, and, as Jessup attested, "the United States staff [at the U.N.] had difficulty in dissuading Cuba" from adopting this course. ${ }^{47}$

To bolster its case against immediate reference to the U.N., the State Department marshalled an array of additional arguments which included the following points. ${ }^{48}$ As non-U.N. members, the three delinquent countries were not bound by the Charter and would certainly refuse to answer charges brought against them in the world organization. ${ }^{49}$ However, they were bound by treaties, ${ }^{50}$ and "broader support could be obtained for UN action if necessary, following utilization of Treaty procedure." ${ }^{51}$ Furthermore, a "UN forum would offer satellites or their friends [the] opportunity to obscure charges of human rights suppression by irrelevant and false counter-charges against other Members which would not be possible in Treaty procedure where issues are confined to obligations of [the] three countries."

As for the airing of the issues-presumably, the main beneficial result of U.N. proceedings - this "could perhaps be obtained through periodic release of documents relating to Treaty procedure which no doubt would extend over [a] long period of time and perhaps through governmental statements outside

45. Id. at 230, 234-36. Invocation of the treaty machinery, according to Secretary of State Acheson, would lessen the possibility of "irresponsible actions" by the U.N. Id. at 236.

46. Within the United States, too, there was some demand for U.N. action. Id. at 233.

47. Jessup, supra note 3 , at 23 . On the Cuban moves, see 5 FOREIGN RELATIONS of THE U.S. 1949, at 233, 235, 237, 239-40.

48. Id. at 236-40.

49. Id. at 237.

50. Id.

51. Id.

52. Id. 
of [the] UN." ${ }^{33}$ In any event, any "consideration of UN sanctions at this time [was] impracticable." ${ }^{\text {s4 }}$ The most that could be expected was Security Council rejection, yet again, of the three satellite states' applications for U.N. membership. But that would hardly represent "effective or persuasive UN action." Moreover, if the Security Council adopted an unfavorable recommendation on admitting the three states, this "would raise important constitutional objections in that it might be interpreted as implied affirmation of [the] view championed by Argentina and opposed by almost all other members including [the] US that [the] Assembly can admit a member regardless [of] S[ecurity] C[ouncil] recommendation."

The U.S. approach prevailed, but not completely. While British cooperation was enlisted for invoking the treaty procedures ${ }^{56}$ and the issue was kept off the Security Council agenda, the General Assembly was seized of the matter in the spring of 1949, earlier than the United States would have wished. ${ }^{57}$

By then, efforts under the treaties were already underway. Though the United States conceded the Assembly's competence to discuss the matter, ${ }^{58}$ it worked successfully to confine Assembly action at that stage primarily to endorsing the initiatives taken by the signatories of the peace treaties. ${ }^{59}$

53. Id.

54. Id. at 238 .

55. Id. at 240. See supra discussion of the Competence case.

56. Telegram from Lewis Williams Douglas, U.S. Ambassador to the U.K., to Dean Acheson, U.S. Secretary of State, 5 FOREIGN RELATIONS OF THE U.S. 1949, at 240-41 (Mar. 25, 1949). For texts of U.S. and British notes, see Peace Treatiescase, 1950 I.C.J. Pleadings 23-30, 72-77. For coordination of statements of denunciation, see 5 FOREIGN RELATIONS OF THE U.S. 1949, at 239. Earlier, the Secretary of State had decided that the United States would proceed unilaterally, if necessary. Id. at 235.

57. The issue was raised by Bolivia on March 16, 1949, U.N. Doc. A/820, with respect to the Mindszenty case, and by Australia, on March 21, 1949, U.N. Doc. A/821, in connection with the observance of fundamental freedoms and human rights in Bulgaria and Hungary, particularly in relation to the recent trials of Catholic Church officials. Before the Fourth Assembly Session, Australia requested that the question of the observance of human rights in Rumania be added to the original item. (U.N. Doc. A/948 [1949]). Australia was, at the time, acting in concert with a "Catholic bloc" in the United Nations on other issues as well-for example, the question of internationalization of Jerusalem. This may have been due to the felt need of the ruling Australian Labor party to woo the Catholic vote. See ABba EBAN, AN AUTOBIOGRAPHY 145-56 (1977).

58. U.N. GAOR General Comm., 3d Sess., 2d Part, 58th mtg. (Apr. 6, 1949), at 8; id., 59th mtg. (Apr. 7, 1949), at 34-35.

59. A Bolivian draft resolution was supported by the United States. It became G.A. Res. 272 (III) (Apr. 30, 1949). For the discussions, see U.N. GAOR Ad Hoc Political Comm., 3d Sess., 2d Part, 34th-4 1st mtgs. (Apr. 19-20, 1949), at 59-176; U.N. GAOR, 3d Sess., 2d Part, 201st-203rd plen. mtgs. (Apr. 29-30, 1949), at 225-73. 
Alternative suggestions, envisaging the immediate establishment of a U.N. investigatory committee, were defeated with the help of the United States. ${ }^{60}$

All efforts at resolving the issue under the rubric of the Peace Treaties proved quickly and clearly abortive. The three communist governments (joined by the Soviet Union) denied the substantiveallegations presented and rejected all diplomatic interventions as unwarranted intrusions in their domestic affairs and processes of justice. They also denied the existence of any dispute between them and the Allied Powers and refused to designate representatives to the treaty commissions provided for in the Peace Treaties. ${ }^{61}$ In these circumstances, and with the Assembly due to resume debate on the issue at its Fall 1949 session, the United States began to map further strategy. Recourse to the Court featured prominently in the State Department planning, although the manner and contours of such recourse apparently engendered some internal debate.

The Department contemplated having the Assembly recommend to the parties, in the first instance, that they refer to the Court for decision either the question of the applicability of the dispute-settlement provisions or the merits of the disputes. ${ }^{62}$ An Assembly request for an advisory opinion (limited to the procedural aspects) would be forwarded to the Court only in the event that the parties failed to refer either matter within six weeks. ${ }^{63}$ Later, however, the first part of the plan was dropped. Since the satellites "will obviously not agree to go to [the] Court on this issue," it was recognized that such a recommendation, would be "a futile gesture." ${ }^{164}$ And, as to submitting the substance of the dispute, the "G[eneral] A[ssembly] has already expressed [the] view that treaty proceedings are appropriate means of settlement and [the] G[eneral] $A[$ ssembly] therefore sh[oul]d not at this stage recommend

60. Such suggestionswere raised by Cuba (U.N. Doc. A/AC.24/48/Rev.2) and Australia (U.N. Doc. A/AC.24/52). A joint Australian-Cuban draft resolution (U.N.Doc. A/AC.24/56) was defeated in committee. U.N. GAOR Ad Hoc Political Comm., 3d Sess., 2d Part, 41 st mtg. (Apr. 22, 1949), at 171-72.

61. On the dispute-settlement procedure, see supra note 38. The Soviet Union argued, inter alia, that the dispute-settlement procedure applied only when all three Allied powers were in controversy with one of the satellite states. See, e.g., U.N. GAOR Ad Hoc Political Comm., 4th Sess., 14th mtg. (Oct. 12, 1949), at 60. For relevant diplomatic exchanges, see Peace Treaties case, 1950 I.C.J. Pleadings 30-69, 77-104. See also 5 FOREIGN RELATIONS OF THE U.S. 1949, at 241-55, 260-61.

62. See also supra note 39, for a discussion of an earlier occasion when the State Department contemplated requesting the Court's opinion on the merits of the dispute.

63. Letter from Dean Acheson, U.S. Secretary of State, to the Embassy in U.K., 5 FOREIGN RELATIONS OF THE U.S. 1949, at 256-57 (July 8, 1949).

64. Letter from Dean Acheson, U.S. Secretary of State, to the Embassy in U.K., id. at 261 (Aug. 3, 1949). 
another means of settlement. . . "65 Rather, the suggested request for an advisory opinion should be adopted directly. ${ }^{66}$

But would not the lack of satellite cooperation make the contemplated resort to the Court's advisory function an equally "futile gesture"? What benefits would be derived from it, and what was the intended follow-up? State Department thinking on these matters was set forth by Secretary Acheson in a message conveyed to the British Foreign Office. "We believe," he stated, "that a judicial determination of the issue . . . is important not only as an additional pressure on the satellites but also as a basis for possible condemnation by the General Assembly of the satellite[s'] refusal to cooperate in the Treaty proceedings according to their international obligations and the recommendation by the General Assembly." ${ }^{167}$ "We must . . . anticipate," Acheson admitted, "that the determination by the Court will not lead to the establishment of commissions under the Treaties. ${ }^{168}$ In that event, he thought that there were several alternative ways by which the General Assembly subsequently might clarify the merits of the dispute, including fact-finding by an impartial jurist appointed by the Secretary-General (a procedure closely approximating the scheme of the treaties); a special committee to investigate the charges (an idea rejected by the General Assembly in its previous session); and inquiry by a subcommittee of the Interim Committee of the General Assembly. ${ }^{69}$ At this stage, however, it was best for the Assembly to limit itself to a recommendation for judicial determination. ${ }^{70}$

Perhaps more important than what the United States hoped to achieve by judicial recourse in this case was what the United States expected to avoid: the precedent of direct Assembly inquiry into human rights violations, on the one hand, and judicial determination of the Assembly's competence in the human rights field, on the other. The following excerpts from Acheson's communication to the British Foreign Office are illuminating:

The above suggested resolution limited to the recommendation for judicial determination might not be enough for such states as Australia, New Zealand, Chile, Cuba and Colombia who were in favor of a more radical Assembly action already last spring. On the other hand, we recall twenty abstentions on the vote to place

65. Id.

66. Id. But, for inconsistency in the Department position on referring the merits of the dispute to the Court, $c f$. statement by Secretary of State Dean Acheson, DEP'T ST. BULL., Oct. 31,1949 , at 495 .

67. Letter from Dean Acheson, U.S. Secretary of State, to the Embassy in U.K., 5 FOREIGN RELATIONS OF THE U.S. 1949, at 257 (July 8, 1949).

68. Id.

69. Id. at 257-58.

70. Id. 
this item on the agenda, the strong reluctance on the part of the Scandinavian countries, most Western Europeans, Arabs, and a number of Latin Americans to support General Assembly action beyond discussion and recommendation of procedural steps as well as the negative attitude of others toward any General Assembly action in this matter. ... We ourselves are somewhat concerned that the General Assembly decision to inquire into the substance of the charges of human rights violations even though Treaty obligations are involved in this particular case might constitute a precedent starting perhaps a long line of cases of charges and counter-charges. As the United States Delegate stated last spring, we believe that the General Assembly's role in this field at this stage of United Nations development should be primarily to promote agreement on common standards and assist in composing differences rather than acting as a court of review on individual cases although the General Assembly in our view is not barred in appropriate circumstances from expressing opinion or making recommendations on this type of case. ...

We would not favor a reference to the International Court of Justice of the question of General Assembly jurisdiction in this matter under Article 2(7) of the Charter. We believe that the General Assembly has jurisdiction to take the steps suggested above. . - However, the Court should not be asked this jurisdictional question at this critical time in the development of international law in the human rights field when the Covenant on Human Rights and the problem of duties of a state towards its own citizens in the International Law Commission are in the process of final formulation."

For its part, the British Foreign Office endorsed the idea of eliciting the Court's advice, but only as to whether the satellites breached their disputesettlement obligations. On this question, the prospects of an affirmative Court response were deemed good. But to ask the additional question regarding the right of the Secretary-General to appoint the "third" members of the treaty commissions (even in the absence of the second members) would not "serve any useful purpose," since the Secretary-General clearly had no such right. ${ }^{72}$

71. Id. at 258. On the delicacy of questions regarding the scope of Article 2(7), see also the comments of the Belgian representative in the General Committee, U.N. GAOR General Comm., 3d Sess., 2d Part, 58th mtg. (Apr. 6, 1949), at 20.

72. Telegram from U.S. Chargé in the U.K. (Holmes) to Secretary of State Acheson (Sept. 7, 1949), 5 ForEigN RELATIONS OF THE U.S. 1949, at 263. 
Nor was the additional question considered necessary. Default on the implementation provisions would be sufficiently incriminating, and the West could justly argue that it "was itself admission of satellites failure to give their people human rights." 73

British advice on restricting the scope of the request was not heeded by the United States in the end, although similar advice was rendered by some members of the State Department and of the U.S. Mission to the United Nations. ${ }^{74}$ The draft resolution introduced by the United States on October 4, 1949 (and cosponsored by Canada and Bolivia) posed four questions to the Court: (1) whether disputes existed within the terms of the peace treaties; (2) whether the three satellite states were obligated to appoint their representatives to the peace treaty commissions; (3) whether, if the three states were so obligated and failed to appoint their representatives, the Secretary-General could appoint the third members of the commissions; and (4) whether such two-member commissions would be competent to make binding decisions. ${ }^{75}$ An Australian amendment to the joint draft resolution would have deleted questions three and four and substituted for the contingent second phase of advisory proceedings the establishment of an ad hoc committee to investigate the substantive human rights issue, regardless of whether the Court's answer to question two would be affirmative or negative. ${ }^{76}$ Other Western states, too, objected to the inclusion of questions three and four, mainly on the grounds that a negative judicial reply was certain, and the task of the Court would be transformed from interpreting to revising treaties. ${ }^{77}$

73. Telegram from U.S. Ambassador to the U.K. (Douglas) to Secretary of State Acheson (Aug. 9, 1949), id. at 262. The Foreign Office also expressed skepticism about the advisability of some of the follow-up procedures suggested by the State Department since they "would drag matters out indefinitely." And without the submission of counterevidence by the satellites, the value of any inquiry would be lessened. Id.

74. In his message of August 25, 1949, Acheson reported to the Foreign Office that "our views on inclusion of this question not yet definite." Id. at 263. Jessup, for one, objected to incorporating the last two questions. Instead of "putting contingent questions to the Court in this fashion," he suggested having the Interim Committee interpret the Court's opinion for the Secretary-General after the first phase of the judicial proceedings. For formulation of the requesting resolution, the U.S. Delegation consulted Professor Manley O. Hudson, the last American judge of the Permanent Court of International Justice. Jessup, supra note 3, at 24.

75. U.N. Docs. A/AC.31/L.1 and A/AC.31/L.1/Rev.1 (1949).

76. U.N. Doc. A/AC.31/L.2 (1949). Australia thought an advisory opinion would prove to be of little assistance in the solution of the problem. U.N. GAOR Ad Hoc Political Comm., 4th Sess., 7th mtg. (Oct. 4, 1949), at 26.

77. See the comments of the French delegate, id., 14th mtg. (Oct. 12, 1949), at 58-59, and U.N. GAOR, 4th Sess., 234th plen. mtg. (Oct. 21, 1949), at 133. See also the statement of Peru that questions 3 and 4 "might be construed as interference in the internal affairs of States through the unilateral interpretation of the peace treaties." U.N. GAOR Ad Hoc Political Comm., 4th Sess., 15th mtg. (Oct. 13, 1949), at 66; U.N. GAOR, 4th Sess., 235th plen. mtg. (Oct. 22, 1949), at 150. Cf. the statement of the Dominican Republic, U.N. GAOR, 4th Sess., 
On the other hand, the U.S. delegate, Benjamin V. Cohen, vigorously defended the joint draft resolution and successfully opposed the Australian amendment. ${ }^{78}$ The General Assembly, he said, was already on record as favoring the use of the treaty machinery, and this approach should be followed through to a "clear and definite conclusion. ${ }^{179}$ It was "in the spirit of [A]rticle 33 of the Charter" that the peace treaty procedures should be exhausted "before the Assembly should attempt to set new or parallel procedures. ${ }^{.80}$ Furthermore, treaty procedures, unlike the Assembly, could yield "a definite decision binding upon the states concerned." 81 The Secretary-General needed to "be advised authoritatively by the Court concerning the scope of his authority," ${ }^{82}$ and it was important to know "whether one party, by refusing to appoint its arbitrator, might make a scrap of paper of its agreement to arbitrate." ${ }^{183}$ This last question was one to which the United States, as signatory, was entitled to receive an authoritative judicial determination. Such a determination, in the U.S. view, was "equally necessary in the interest of the development of international law and of the community of nations under the Charter. ${ }^{184}$ For its part, the United States pledged to accept the Court's opinion on all the questions as binding and expressed the hope that the three satellite states would do the same. ${ }^{85}$

234th plen. mtg. (Oct. 21, 1949), at 139. The U.K. representative, though he now favored reference of questions 3 and 4 to the Court, deemed a negative judicial response probable. Id. at 144. In the Ad Hoc Political Committee, Britain abstained on the Australian amendment. U.N. GAOR Ad Hoc Political Comm., 4th Sess., 15th mtg. (Oct. 13, 1949), at 66.

78. The vote to defeat the amendment was 29 to 5 , with 22 abstentions. Id.

79. Benjamin V. Cohen, Debate on Human Rights-Freedom Can Unite Us (Statement of Oct. 4, 1949, in G.A. Ad Hoc Political Committee), DEP'T ST. Bull., Oct. 24, 1949, at 622 [hereinafter Debate].

80. Id. at 617.

81. Id.

82. Id. at 623 .

83. U.N. GAOR, 4th Sess., 234th plen. mtg. (Oct. 21, 1949), at 131.

84. Debate, supra note 79, at 624. Regarding the hesitations of the Soviet and French representatives to have question four put to the Court, Cohen queried why, if they were so sure that the question would be answered in the negative, they "oppose, rather than welcome, an impartial and definite decision" on the matter. Benjamin V. Cohen, Debate on Violation of Human Rights in Eastern Europe Continued (Statement of Oct. 12, 1949, in G.A. Ad Hoc Political Committee), DEP'T ST. BULL., Oct. 31, 1949, at 660 [hereinafter Debate Continued]. Cf. the support of India in the Ad Hoc Political Committee for referring questions 3 and 4, too, because the Court's answer would have a bearing on the drafting of future treaties. U.N. GAOR Ad Hoc Political Comm., 4th Sess., 10th mtg. (Oct. 7, 1949), at 40. However, India later abstained on the resolution to request the advisory opinion. U.N. GAOR, 4th Sess., 235th plen. mtg. (Oct. 22, 1949), at 150.

85. Debate, supra note 79, at 623; Debate Continued, supra note 84, at 660 . See also Statement by Secretary Dean Acheson, Address of Secretary of State Dean Acheson at G.A. Plenary, Sept. 21, 1949, DEP'T ST. BULL., Oct. 3, 1949, at 150. 
Realistically, the United States entertained no such hope, and its insistence on including questions three and four was itself testament to that fact. Soviet opposition to recourse to the Court was firm ${ }^{86}$-and predictably so, given the nature of the accusations, which underlay the request. Even more than in the Admission case, the Western complaints exposed a raw nerve in the Communist world. Involved in this request were no "accidental phenomena, but the inevitable consequences of their [the satellites'] political and social structure. ${ }^{87}$ In these circumstances, little could be gained from sucking the Court into the controversy, ${ }^{88}$ but vital assets of the Court might be lost. However, only the Soviet bloc members professed any concern over the consequences of the request for the future authority of the Court. It was wrong, they protested, to make the Court a tool of the Cold War and transform it "into a mere branch of the State Department or the Foreign Office. ${ }^{189}$ The majority of U.N. members proceeded to endorse the request, ${ }^{90}$ though several expressed skepticism about its utility. ${ }^{91}$

From the U.S. perspective, involvement of the Court was simply a necessary last step in the course of exhausting the treaty procedures-a course

86. For a summary of the legal arguments presented, see POMERANCE, supra note 5, at 100-02. The Soviets were especially opposed to questions 3 and 4. U.N. GAOR Ad Hoc Political Comm., 4th Sess., 14th mtg. (Oct. 12, 1949), at 60 (comments of Vyshinsky).

87. Statement of The Netherlands, U.N. GAOR Ad Hoc Political Comm., 4th Sess., 1 th mtg. (Oct. 10, 1949), at 44. See also the comment of Benjamin V. Cohen, that the human rights violations by the satellites were "the results . . of the world-wide effort by the Soviet Union to use the world Communist movement as an instrument for carrying out by force and stealth its own imperialist objectives." Benjamin V. Cohen, Problem of Human Rights in the Balkans (Statement in G.A. Plenary, Oct. 21, 1949), DEP'T ST. BULL., Nov. 7, 1949, at 692.

88. An affirmative answer to the first two questions would presumably make clear to the world that the three governments, on top of their violations of obligations concerning human rights and fundamental freedoms, also violated their commitments regarding dispute settlement. If, in addition, the Court were to reply affirmatively to questions 3 and 4 (an unlikely prospect), the substantive accusations against the satellites might be upheld by treaty commissions, thus increasing, in some measure, the embarrassment of those governments.

89. See U.N. GAOR Ad Hoc Political Comm., 4th Sess., 12th mtg. (Oct. 11, 1949), at 48 (comments of Vyshinsky). See also U.N. GAOR, 4th Sess., 234th plen. mtg. (Oct. 21, 1949), at 134 (comments of Polish delegate).

90. After separate votes on each of the four questions, the joint draft resolution, as a whole, was adopted in the Ad Hoc Political Committee by a vote of 41 to 5, with 9 abstentions, and in Plenary by a vote of 47 to 5, with 7 abstentions. U.N. GAOR Ad Hoc Political Comm., 4th Sess., 15th mtg. (Oct. 13, 1949), at 66; U.N. GAOR, 4th Sess., 235th plen. mtg. (Oct. 22,1949 ), at 150. There was less support for submitting questions 3 and 4 , and there were a larger number of abstentions. Id.

91. See especially, U.N. GAOR Ad Hoc Political Comm., 4th Sess., 7th mtg. (Oct. 4, 1949), at 26 (statement of Australia); id., 14th mtg. (Oct. 12, 1949), at 58-59 (statement of France). 
to which the United States came to be obsessively committed. ${ }^{92}$ This commitment, in turn, was probably prompted only to a small degree by a self-deluding assumption that a "binding" decision could make a difference, that it might induce change in satellite behavior. More importantly, the United States needed to appear to be doing the maximum for the embattled satellite populations, while eschewing more forceful actions, such as sanctions or U.N. actions preparatory to sanctions. It also clearly preferred judicial pronouncements on the competence of treaty commissions to judicial clarification of the competence of the General Assembly in the sphere of human rights. But in opting for what was, from its standpoint, the lesser evil, the United States omitted to appraise the "evil" of this preference from the standpoint of the Court and its still fragile standing in the world community.

\section{Expenses}

A similar insensitivity to the Court's interests characterized the American attitude some twelve years later, when the United States was again actively engaged in the process of seeking the Court's advice on a matter sharply in contention between the two superpowers. Nor did the United States exhibit any particular perspicacity in weighing its stakes in procuring the judicial imprimatur for its stand.

As in the Admission case, the Court was called upon to select between alternative interpretations of Charter provisions bearing on the internal functioning of the Organization. But unlike the earlier case, the implications of the Court's ruling were potentially more far-reaching. In the background lurked the sanction provided for in Article 19 of the Charter, ${ }^{93}$ which theoretically could be employed to pressure the Soviets to comply with a Court opinion. At the pre-request and early post-opinion phases, the United States appeared determined to resort to this sanction if necessary-unaware that most other U.N. members were disinclined to acquiesce in such a course, and unaware, too, that America's own long-range interests would not necessarily be served by a favorable Court opinion.

92. The United States went as far as to anticipate the Court's opinion and to appoint, in advance, its commissioner to the treaty commissions. See 5 FOREIGN RELATIONS OF THE U.S. 1949, at 271-76 (1976).

93. Article 19 of the U.N. Charter provides:

A Member of the United Nations which is in arrears in the payment of its financial contributions to the Organization shall have no vote in the General Assembly if the amount of its arrears equals or exceeds the amount of the contributions due from it for the preceding two full years. The General Assembly may, nevertheless, permit such a Member to vote if it is satisfied that the failure to pay is due to conditions beyond the control of the Member. 
The context in which the Court's opinion was sought was the threatened insolvency of the United Nations resulting from the failure of many states to share in the expenses of one or both of the costly peacekeeping operations then in progress-UNEF (the U.N. Emergency Force in Sinai) and ONUC (the U.N. Force in the Congo). Within the Assembly, no consensus had emerged on the proper method of financing the forces or on the question whether members were legally obligated to contribute. Most prominent among the non-contributors were the Soviet Union (which contributed to neither peacekeeping force) ${ }^{94}$ and France (which demurred only on paying for ONUC). In 1961, as the financial crisis deepened, the Assembly established a Working Group of Fifteen (including the United States) to recommend solutions. ${ }^{95}$ But the differences among the members proved unbridgeable,${ }^{96}$ and the Working Group could agree only to endorse a Canadian suggestion to seek the International Court's advice with respect to "the legal nature of financial obligations arising out of peace-keeping operations. ${ }^{197}$ In the Fifth Committee, that suggestion was translated into a formal proposal co-sponsored by the United States. ${ }^{98}$ As formulated, the request related no longer to expenditures for peacekeeping operations in the abstract, but rather to the particular expenditures already incurred for UNEF and ONUC. ${ }^{99}$ Moreover, the question no longer specifically mentioned the

94. The Soviet Union's nonpayment of UNEF expenses was based on the view that the Assembly had authority neither to establish the force nor to finance it. In the case of ONUC-which was set up by the Security Council and hence was unobjectionable on that score-Soviet opposition centered on the manner in which the Council's directives were implemented by the Secretary-General and on the fact that the expenses for the operation were again, as in UNEF, apportioned by the General Assembly.

95. G.A. Res. 1620 (Apr. 21, 1961). The full name of the unit was the Working Group of Fifteen on the Examination of the Administrative and Budgetary Procedures of the United Nations.

96. The extent of the differences is graphically revealed in the Report of the Working Group, U.N. Doc. A/4971 (in U.N. GAOR, 16th Sess., Annexes, Agenda Item 62), paras. 7-23 and Annex II (1961).

97. The formulation of the question was to be determined by the General Assembly. For U.S. endorsement of the Canadian suggestion, see U.N. Doc. A/AC. 104/SR.11, at 7 (1961). The Soviet bloc objected, mainly because the issue was "political," and also because the matter was deemed too clear to warrant soliciting an advisory opinion. U.N. Doc. A/AC.104/SR.10, at 4 (1961); U.N. Doc. A/AC.104/SR.Il, at 6(1961); U.N. Doc. A/AC.104/SR.12, at 4(1961). See also the objections of India, U.N. Doc. A/AC.104/SR.10, at 8 (1961).

98. U.N. Doc. A/C.5/L.702 \& Add. 1-2 (1961). The other sponsors were Brazil, Cameroun, Canada, Denmark, Japan, the United Kingdom, Liberia, Pakistan, and Sweden.

99. Thus, the question now possessed a retrospective aspect which a general question on peacekeeping operations for future guidance might have avoided. On this ground, among others, Judge Basdevant considered that the Court should have declined to give the opinion requested. "Where," he said, "it would have been possible to obtain from an opinion requested of the Court collaboration in the present work of the United Nations, it has been sought to 
financial obligations of member states. The Court was asked merely whether the expenditures incurred "constitute 'expenses of the Organization' within the meaning of Article 17, paragraph 2, of the Charter."100 The proposal was adopted by the Fifth Committee and in Plenary, ${ }^{101}$ but only after a lively debate both on the idea of soliciting the Court's advice and the terms of the question posed.

The United States, along with the other sponsors and supporters of the draft resolution, insisted that a Court opinion would help break the impasse. These nations believed a clearer definition of "the rights and obligations of each Member with respect to the United Nations" would be a necessary, if not sufficient, component of a solution. While "the question did have political implications . . . essentially it was a legal question."102

Soviet opposition to the request was predictably firm, in line with the traditional Soviet posture whenever recourse to the Court was at issue. In this case, the Soviets had additional cause to object, since the aim of the proposal was to pressure the Soviets to bear the costs of political actions to which they objected. ${ }^{103}$ Arguing against requesting an advisory opinion, the Soviet representative contended, first, that the issue was clearly settled by the Charter and that the projected consultation of the Court would be equivalent to undermining the essential principles which member states had accepted upon signing the Charter. Second, the problem was essentially political and was not separable into legal, financial, and political elements. And finally, there was no need to seek judicial advice, since the requisite financing could and should be arranged in accordance with Article 43 of the Charter. The Soviet representative further served notice on the Assembly that his government would not consider itself bound by any Court decision because the question was not within the Court's competence. ${ }^{104}$

obtain from the Court only a retrospective evaluation of what was done up to the end of 1961." Certain Expenses of the United Nations (Art. 17, para. 2, of the Charter), 1962 I.C.J. REP. 151 , at 237-38.

100. In the preamble, however, the Assembly recognized its need "for authoritative legal guidance as to obligations of Member States under the Charter of the United Nations in the matter of financing the United Nations operations in the Congo and in the Middle East." The Court discounted the importance of this preamble. Id. at 157-58. But compare the separate opinion of Judge Fitzmaurice. Id. at 198.

101. U.N. GAOR 5th Comm., 16th Sess., 899th mtg. (Dec. 11, 1961), at 299; U.N. GAOR, 16th Sess., 1086th plen. $\mathrm{mtg}$. (Dec. 20, 1961), at 1153-54. The resolution was numbered 1731 (XVI).

102. U.N. GAOR 5th Comm., 16th Sess., 897th mtg. (Dec. 8, 1961), at 290.

103. The Congo operation, especially after the initial period of its existence, was viewed by the Soviet Union as directed against its influence in the region.

104. Id. at 289; id., 898th mtg. (Dec. 8, 1961), at 295; U.N. GAOR, 16th Sess., 1086th plen. mtg. (Dec. 20, 1961), at 1151-52. See also U.N. GAOR 5th Comm., 16th Sess., 897th mtg. (Dec. 8, 1961), at 290 (Rumanian argument). 
The French attitude was no more encouraging. Despite the fact that France had, in the Working Group, endorsed the recommendation to consult the Court, ${ }^{105}$ the French representative now argued quite forcefully against such a course of action. For several reasons, he thought the product of the consultation could only be, at best, inconclusive, and at worst, positively harmful. The judges would find no guidance in the travaux préparatoires. U.N. debates and practice revealed that contributions to peacekeeping expenditures had become, in the opinion of many member states, purely optional. In addition, the national composition of the Court was not very different from that of the Working Group, and, although independent, the judges rarely adopt views contrary to those taken by their respective governments. As a result, a number of dissenting opinions would probably be involved, thus weakening the value of any opinion. Recourse to the Court would probably aggravate the situation by rigidifying the attitudes of governments, and would also cause a year's delay in the initiation of the necessary financial reforms. ${ }^{106}$

The terms of the question posed were also strongly criticized, especially by France, which proceeded in Plenary to offer an amendment designed to broaden the scope of the request. In answering the question as framed, France contended, the Court could not "elucidate the question of the Assembly's own powers or lack of powers in financial matters"; nor could it consider such other provisions as Articles $10,11,12,14$, and 19 , all of which were highly relevant to the problem confronting the Assembly. ${ }^{107}$ Under the terms of the French amendment, the Court would have beeri asked to determine whether the resolutions authorizing the UNEF and ONUC expenditures were "decided on in conformity with the Charter," and, only in the event of an affirmative answer, the further question of whether the expenditures constituted "expenses of the Organization." 108

105. France had merely insisted that the Sixth Committee be consulted with respect to the drafting of the question. U.N. Doc. A/4971, para. 25 (1961).

106. U.N. GAOR 5th Comm., 16th Sess., 897th mtg. (Dec. 8, 1961), at 291.

107. Id., 899th $\mathrm{mtg}$. (Dec. 11, 1961), at 300. Criticism was also voiced by the representatives of Peru and Mexico, both of whom felt that the applicability of Chapter VII should have been included in the request. See id., 897th mtg. (Dec. 8, 1961), at 291-92; id., 899th mtg. (Dec. 11,1961 ), at 300-01 (statement of China). The Peruvian, French and Mexican representatives also criticized the failure of the Fifth Committee to consult the Sixth Committee on the precise formulation of the question, in accordance with the procedure outlined in G.A. Res. 684 (VII) (Nov. 6, 1952) and incorporated in Annex II of the Assembly's Rules of Procedure. Id., 897th mtg., at 289-92; 899th mtg., at 300-01. Cf. U.N. GAOR, 16th Sess., 1086th plen. mtg. (Dec. 20,1961 ), at 1153 (U.S. response that consultation of the Sixth Committee was only optional).

108. As the Court later noted, the French amendment would have had the Court consider the validity only of the resolutions authorizing the expenditures, not of the basic resolutions establishing UNEF and ONUC. Certain Expenses of the United Nations, 1962 I.C.J. REP. 156. 
The U.S. representative deemed criticism of the formulation of the request to be unfounded. "It was not the view of the sponsors," he said, "that the Court should confine itself to an examination of Article 17 of the Charter." Rather, "it should consider the Charter as a whole" and handle the question "exhaustively and in all its aspects." ${ }^{109}$ The motives of the French representative in pressing his amendment in plenary were viewed with a jaundiced eye by the U.S. representative:

It is illuminating to observe that in the debates in the Fifth Committee the proponent of the amendment opposed the whole idea [of recourse to the Court]. The purpose of an amendment urged in these circumstances requires extraordinary reasons to justify its acceptance. ...

This amendment, in accordance with French opposition to the very idea of seeking the Court's opinion, does not clarify the questions at issue. Rather, it would tend to confuse it. At an hour when the United Nations is exerting its utmost efforts in the Congo, such confusion and elaboration of what is essentially a simple issue would be legally and psychologically most unfortunate. ${ }^{110}$

American suspicions were understandable. Though ostensibly designed to expand the scope of judicial inquiry and enhance the effectiveness of the consultation, ${ }^{111}$ the French amendment represented, more plausibly, a maneuver aimed at defeating the draft resolution altogether. Many states, fearful of the expanded role to be assigned to the Court in assessing the legality of General Assembly actions, could be expected to withdraw their original support of submission of the problem to the Court. ${ }^{112}$

As urged by the United States, the Assembly Plenary proceeded to defeat the French amendment ${ }^{113}$ and to adopt the Fifth Committee's draft resolution

109. U.N. GAOR, 16th Sess., 1086th plen. mtg. (Dec. 20, 1961), at 1153.

110. Id. For the statements of Canada, U.K. and El Salvador, see id. at 1152-54.

111. Id. at 1151,1154 (French explanation).

112. Significantly, the Soviet representative supported the amendment, and, for its part, France manifested an unsympathetic attitude to the entire idea of consulting the Court in this case, with or without the amendment. Id. at 1151-52, 1154.

113. It was defeated by a vote of 47 to 5 , with 38 abstentions. $I d$. at 1153 . The implications of the rejection of the French amendment later proved to be an issue of considerable contention, both in the pleadings before the Court and among the members of the Court themselves. See, e.g., Certain Expenses at United Nations, 1962 I.C.J. Pleadings 167-70, 203-04 (written statements of the United States and the Netherlands). For the oral statements of the U.K., Norway, Australia, Ireland, and the United States, see id. at 336, 352, 384, 387-89, 416. See also Certain Expenses of United Nations, 1962 I.C.J. REP. 157; id at 182ff., 216ff. (separate opinions of Judges Spender 
to request the Court's opinion. ${ }^{114}$ American satisfaction with the outcome notwithstanding, it must be said that neither the decision to involve the Court in this case nor the formulation of the question bore the marks of much forethought. As even the sponsors of the draft resolution recognized, the basic problem was, after all, the empty coffers of the organization. In what way, then, could a Court opinion contribute to a solution of this problem? Surely not by virtue of the "moral force" or "authoritativeness" of such an opinion. Experience with earlier judicial pronouncements such as those in the Admission and Peace Treaties cases must have proved to all-if such proof was necessary-how unamenable the Soviet Union was to that particular form of influence. Nor, for that matter, was it realistic to expect the other major defaulter, France, to bow willingly to a Court opinion.

Undoubtedly, it was the theoretical availability of the Article 19 sanction which was expected to "persuade" the defaulters to mend their ways. ${ }^{115}$ But could the sanction realistically be used against a major power? And if it could not, but was merely to be held in reserve as a threat, was it, then, a credible threat? Moreover, if the matter eventually had to be settled by negotiations-if it was to be settled at all-why involve the Court in such a controversial issue and risk impairing the Court's prestige? If, indeed, these questions engaged the minds of U.S. decision-makers, there is no indication of this on the record.

Some members of the nonaligned bloc took a more realistic view of the matter. The Ceylonese representative, especially, voiced far-sighted objection:

The present de facto situation could be altered only through the co-operation of Member States and particularly of the great Powers. An affirmative answer by the Court would only tend to complicate a situation which was already sufficiently complex. Such an answer would be of little value if a great Power still refused to pay its share of the present peace-keeping operations, and he doubted that much advantage would be gained by depriving that Power of membership in the United Nations on the basis of the Court's opinion. Legality could be of little value if it could not ensure compliance. Therefore, a practical approach involving a recognition of both reality and legality appeared preferable.

and Morelli).

114. The vote was 52 to 11 , with 32 abstentions. Only the Soviet bloc and France voted in opposition, while a majority of the non-aligned Afro-Asian states were among the abstainers.

115. Although Article 19 had not been mentioned by the United States or any of the draft resolution's sponsors, it was alluded to by other states and formed an unstated major premise of the decision to seek the Court's advice. See U.N. GAOR 5th comm., 16th Sess., 899th mtg. (Dec. 11, 1961), at 299-300 (statement of Australia). 
Co-operation could not be achieved through compulsion.... [T] he attempt to refer the present issue to the International Court was futile and negative. ${ }^{16}$

The futility of the exercise apart, it is perhaps puzzling that U.S. decisionmakers were so dedicated to procuring judicial endorsement of an expansive view of the General Assembly's budgetary and other powers at the very time the composition of the Assembly was changing so drastically. The new General Assembly could, quite predictably, be galvanized more readily against U.S. than against Soviet interests. Would the United States in the future be so anxious to enforce, against itself, any and all expenses decreed by a majority of the Assembly? It was only in 1965, with the enunciation of the "Goldberg Reservation,"117 that the United States began to operate on a revised premise. In the pre-request period and in the immediate aftermath of the opinion, such foresight appeared notably absent. ${ }^{118}$

\section{SOME ABortive "COLD WAR" ReQUESTS}

\section{A. Soviet Exit Visas}

Nearly a year before the Assembly turned to the Court for advice on preliminary procedural questions related to human rights observance in Soviet

116. U.N. GAOR 5th Comm., 16th Sess., 898th mtg. (Dec. 8, 1961), at 296. Cf. id., 897th mtg (Dec. 8, 1961), at 289 (statement of India); id., 899th mtg. (Dec. 11, 1961), at 301 (statements of Afghanistan and Indonesia).

117. On August 16, 1965, U.S. Ambassador Arthur Goldberg, in a statement which brought the "Article 19 crisis" to an end, also enunciated a new U.S. policy with regard to the withholding of contributions to the United Nations. Speaking in the U.N. Special Committee on Peacekeeping Operations, Goldberg stated:

[W] ithout prejudice to the position that article 19 is applicable, the United States recognizes, as it simply must, that the General Assembly is not prepared to apply article 19 in the present situation and that the consensus of the membership is that the Assembly should proceed normally. We will not seek to frustrate that consensus, since it is not in the world interest to have the work of the General Assembly immobilized in these troubled days. At the same time, we must make it crystal clear that if any member can insist on making an exception to the principle of collective financial responsibility with respect to certain activities of the organization, the United States reserves the same option to make exceptions if, in our view, strong and compelling reasons exist for doing so. There can be no double standard among the members of the organization.

U.N. Doc. A/AC.121/PV.15, at 8-10 (1965); U.N. Doc. A/5916/Add.1, in U.N. GAOR, 9th Sess., Annex 21, at 86 (1965).

118. See POMERANCE, supra note 5, at 351-52, 361-64. 
satellite states, the Assembly's Sixth Committee considered and rejected a proposal to involve the Court in a substantive question bearing on the observance of human rights by the Soviet Union itself. In this instance, the U.S. attitude was ambivalent, with members of the American mission to the United Nations sharing the skepticism of several other key Western U.N. delegations regarding the utility of a judicial consultation. Other courses of action were thought to entail less risk and more potential propaganda benefits.

The complaint which formed the basis of the Assembly's 1948 discussions of Soviet violations of "fundamental human rights, traditional diplomatic practices and other principles of the Charter" was the special problem of the former Chilean Ambassador to the Soviet Union. His Russian daughter-in-law had been refused permission to leave the Soviet Union with her husband. By this action, Chile contended, the Soviets had violated both general human rights norms governing family unity and free emigration and particular norms governing "diplomatic practices traditionally consecrated by international law." 119 Chile expressed willingness to have its controversy with the Soviet Union adjudicated by the Permanent Court of Arbitration or the International Court of Justice, but its offer for joint reference to either body was rebuffed by the Soviet Union. ${ }^{120}$ In these circumstances, the idea of getting the matter to the Court by the advisory route appeared to some-including the U.S. State Department-as a logical alternative approach. ${ }^{121}$ In its recommendations to the U.S. Delegation to the United Nations, the State Department urged U.S. support for a resolution to solicit a Court opinion on the legality of the Soviet action in the matter of the Chilean Ambassador's daughter-in-law.

Although the Department's recommendations were formally approved by the Delegation, internal debate revealed considerable reservations about their wisdom. It was recognized at the outset that only the specific Chilean-Soviet controversy entailed any legal issue at all. "As to the general problem of the detention of the Soviet wives of citizens of various countries," though the Soviet practice was undesirable and inhuman and though it also directly affected U.S. citizens, ${ }^{122}$ there was "no legal obligation on the part of the Soviet Union to permit these persons to leave."123 But even the Chilean case was thought by some to have a tenuous legal basis. Emest Gross, in particular, pointed out that while "there were well established rules of international law ... regarding the

119. Letter from H. Santa Cruz, Chilean U.N. Ambassador, to the Secretary-General (May 27, 1948), U.N. Doc. A/560 (1948); U.N. Doc. A/C.6/296 (1948).

120. See U.N. GAOR 6th Comm., 3rd Sess., 1st Part, 135th mtg. (Dec. 3, 1948), at 728; id., 139th mtg. (Dec. 7, 1948), at 779.

121. See 1 FOREIGN RELATIONS OF THE U.S. 1948, at 294; Jessup, supra note 3, at 22.

122. The number of U.S. citizens affected by the refusal of exit visas for their Soviet wives was variously estimated at 1,000 (Sandifer's figure in 1 FOREIGN RELATIONS OF THE U.S. 1948, at 293) and 350 (U.N. GAOR 6th Comm., 3d Sess., 1st Part, 135th mtg. (Dec. 3, 1948), at 735.

123. I FOREIGN RELATIONS OF THE U.S. 1948, at 294. 
status of the retinue of a diplomatic envoy," the "question of the status of the members of their families was still an open one." 124 He considered it "unfortunate" that the item had been referred to the Sixth (Legal) Committee, "since it meant that it would be discussed by lawyers who might miss the broad questions of human rights which were involved." ${ }^{125}$ For other members of the Delegation, too, it was clearly the broader question that needed emphasizing. As noted by one member (Eleanor Roosevelt concurring), the agenda item "afforded the United States a beautiful propaganda opportunity."126

The privately voiced skepticism of Gross regarding the legal-judicial approach to the problem was later publicly re-echoed by several Western delegations in the Sixth Committee's discussions in early December 1948. An Australiansponsored draft resolution to request a Court opinion on the legality of Soviet violation of traditional diplomatic practices ${ }^{127}$ met with a notable lack of enthusiasm. For example, the United Kingdom Delegate, Mr. (later Judge) Fitzmaurice, stated unequivocally that the matter was not strictly a legal one; rather, it involved the issues of human rights, "normal diplomatic usage" and "simple international courtesy." ${ }^{128}$ Moreover, he asserted, a Court opinion was unnecessary and would not contribute to a solution of the basic problem. If the disputed actions were deemed illegal, "the principals in the case would still be in the Soviet Union"; and if those actions were upheld on legal grounds, the Soviet authorities "would still be in the position of having violated fundamental human rights." 129 The French delegate, M. Chaumont, also thought that the "human aspect ... should over-ride any legal consideration." ${ }^{130}$

124. Id. at 294-95.

125. Id. at 295.

126. See id. (Mr. Thorp's remarks).

127. U.N. Doc. A/C.6/316 (1948). The questions to be referred to the Court were:

1. To what degree do the privileges and immunities granted to the head of a foreign mission in accordance with diplomatic practices traditionally established by international law extend to his family and to his establishment?

2. In particular, is the action of a State in preventing one of its nationals, who is the wife of a member of a foreign diplomatic mission or of a member of his family or of his establishment, from leaving its territory with her husband, or in order to join her husband, a breach of international law?

128. U.N. GAOR 6th Comm., 3d Sess., 1st Part, 135th mtg. (Dec. 3, 1948), at 733; id., 137th mtg. (Dec. 6, 1948), at 751-52 (1948). See also id., 139th mtg. (Dec. 7, 1948), at 781 (1948); and U.K. amendment, U.N. Doc. A/C.6/311 (1948), to the original Chilean proposal, U.N. Doc. A/C.6/296 (1948). The U.K. wished to replace "international law" with the expression "international usage and courtesy." See also infra text at notes 131 \& 136 for the terms of the adopted resolution.

129. U.N. GAOR 6th Comm., 3d Sess., 137th mtg. (Dec. 6, 1948), at 752.

130. Id. at 751 (1948). The French delegate conceded that "[t]he question whether the person concerned was protected by diplomatic immunity was still a doubtful one." $I d$. at 750 . See also id, 138th mtg. (Dec. 7, 1948), at 766 (comments of the Greek delegate). 
Besides being futile, M. Dupuy of France added, the proposed judicial recourse would be positively harmful. By turning to the Court, the Assembly would show indecisiveness and would "weaken the significance" of the resolution that it had already adopted, in which Soviet behavior had been pronounced, inter alia, "contrary to courtesy, to diplomatic practice, and to the principle of reciprocity." ${ }^{131}$ Even Canada, one of the few states which supported the judicial consultation, took pains to stress that it should not be a means of disposing of the question, and that regardless of the outcome, the Assembly was justified in objecting to the Soviet actions and demanding rectification. ${ }^{132}$

Ambassador Gross, the U.S. delegate, "deplored" the refusal of the Soviet Union to submit its dispute with Chile to the Permanent Court of Arbitration or the International Court of Justice. ${ }^{133}$ Nevertheless, he concurred with the United Kingdom view that "it was not for the Committee to deal with the questions raised by the Australian draft resolution" since "the whole problem was one of fundamental human rights."134 Most of the U.S. statement was indeed devoted to the human rights aspects of the question, and the substantive legal issue was barely addressed. ${ }^{135}$

In the vote, the United States supported the draft resolution in which the Assembly objected to, and recommended the withdrawal of, Soviet measures denying exit visas to Soviet wives of foreign citizens, in general, and the application of those measures to "members of foreign diplomatic missions, their families or retinue," in particular. ${ }^{136}$ How the United States voted on the Australian proposal is not indicated by the record. ${ }^{137}$

\section{B. The Aftermath of the Competence Case}

From the records of the State Department, it is clear that there was extensive consideration of the possibility of involving the Court once more in the admission

131. Id, 139th $\mathrm{mtg}$. (Dec. 7, 1948), at 780. The resolution adopted was based on a FrenchUruguayan amendment, U.N. Doc. A/C.6/319 (1948). See Report of the 6th Comm., U.N. Doc. A/787 (1948).

132. U.N. GAOR 6th Comm., 3d Sess., 1st Part, 138th mtg. (Dec. 7, 1948), at 759-60.

133. Id., 135th mtg. (Dec. 3, 1948), at 738 .

134. Id., 137th mtg. (Dec. 6, 1948), at 757 .

135. See id., 135th $\mathrm{mtg}$. (Dec. 3, 1948), at 735-39; id. at 738 (the lone brief reference to diplomatic privileges and immunities).

136. See id., 139th mtg. (Dec. 7, 1948), at 777; id., 197th plen. mtg. (Apr. 25, 1949), at $162-63$.

137. The proposal was defeated in Committee by a vote of 9 for, 13 against, and 12 abstentions. Id., 6th Comm., 139th mtg. (Dec. 7, 1948), at 781 . 
imbroglio in the years $1951-1953 .^{138}$ On several occasions, the State Department evinced an inclination to acquiesce, albeit reluctantly, in further recourse to the Court, since other solutions for breaking the impasse that various Latin-American states, at the instigation of Italy, actively pressed were perceived as far more injurious to U.S. interests. In particular, the United States feared that the other alternatives "could lead to a gradual whittling away of the veto power." ${ }^{139}$ Nevertheless, the State Department was fairly consistent in expressing reservations about the utility of the judicial option. It also strove to ensure a more felicitous drafting (from its standpoint) of any question which might be sent to the Court. In those years, too, the United States continued to withstand growing pressures for a package deal on admissions-an idea which ran counter to the thrust of the Court's opinion in the Admission case and also raised domestic and international political difficulties for the United States.

The strong desire of Italy to be admitted to the United Nations was the principal driving force behind persistent multifarious Latin-American efforts to devise a method that would circumvent the Soviet veto on membership questions. Like the Latin-American states, the United States sympathized with Italy's aspirations. In the Tripartite Declaration of September 26, 1951, it had pledged (along with France and the United Kingdom) to "make every effort" to secure Italy's admission. ${ }^{140}$ And clearly, the United States was not impervious to Italy's repeated raising of the specter of Communist gains in Italy should the democratic government's foreign policy goals be frustrated. ${ }^{141}$ But unlike the Latin American states, the United States was unwilling to countenance Italy's idea of "stretching the Charter" in this case-even as the General Assembly had done when it adopted the Uniting for Peace Resolution, and as the Security Council had acted when it evaded the "double veto" procedure via presidential rulings. From the long-range perspective, the United States deemed such initiatives nefarious.

In several of the Latin American initiatives, there was a judicial component-suggestions for further requests for advisory opinions or for bypassing previous opinions. Moreover, at various junctures (and primarily in order to avoid more serious denouements), members of the U.S. Delegation to the United Nations themselves (and even Secretary of State Acheson on two separate occasions) raised the possibility of soliciting a Court pronouncement

138. See 2 FOREIGN RELATIONS OF THE U.S. 1951, at 347-454 passim (discussing admission of Italy to the U.N.); 3 FOREIGN RELATIONS OF THE U.S. 1952-1954, at 826-37, 855, 868, 872-95 passim, 919-69 passim, 1031, 1049-51.

139. Id. at 829-30.

140. Removal of Certain Restrictions from Italian Treaty Favored, DEP'T ST. BULL., Oct. 1951, at 570 .

141. See, e.g., 2 FOREIGN RELATIONS OF THE U.S. 1951, at 391, 393, 449, 453; 3 FOREIGN RELATIONS OF THE U.S. 1952-1954, at 854. 
regarding the effect of specific Soviet vetoes on admissions. The most pertinent suggestions, and the American reactions to them, may be summarized briefly.

1) According to a plan presented in 1951 by Mr. Belaunde of Peru, applicants for admission would bring proof to the Security Council of their qualifications under Article 4. In the event of a veto threat, the Assembly would request an advisory opinion on the value of the proof offered; and a favorable opinion on the matter would bind the Security Council and render the matter no longer subject to veto. ${ }^{142}$ This initiative was strongly opposed by the State Department, which noted, inter alia, that Soviet vetoes, even when improperly used, were not void; that a State was not required to explain its vote on admissions; and that, in any event, the Soviet Union could easily invoke alleged Charter grounds-including, for example, Italy's membership in NATO as proof of its non-peace-loving nature. Furthermore, the Court might well consider itself incompetent to give an opinion, since in the Admission case, it had stated that "no relevant political factor ... connected with conditions of admission is excluded." 143 The United States itself objected to submitting to the Court "an issue . . . so predominantly political in character."144 In any case, the United States firmly opposed the elimination of the veto from admissions procedures, and it was unwilling to sanction Charter-stretching exercises (including the extension of the power of presidential rulings in the Security Council) lest dangerous precedents be thereby created. ${ }^{145}$

2) In internal discussions and memoranda in 1951 during the sixth General Assembly session, the idea of asking for judicial advice was put forward by, among others, Secretary of State Acheson and some members of the U.S. Delegation to the United Nations. ${ }^{146}$ As noted earlier, the chief purpose in making these suggestions was to forestall demarches deemed objectionable by the United States, such as direct General Assembly action despite a veto in the Security Council, or the adoption of a procedure permitting the Security Council President to rule on the effect of a permanent member's negative vote, thereby greatly extending the evasion of the "double veto." 147 Although

142. See 2 FOREIGN RELATIONS OF THE U.S. 1951 at 361, 370, 372 n.4.

143. Admission of a State to the UnitedNations (Charter, Art. 4), Advisory Opinion, 1948 I.C.J. REP. 63.

144. 2 FOREIGN RELATIONS OF THE U.S. 1951, at 353.

145. Similar arguments were to be repeated whenever the issue of further advisory opinions on the admission problem was raised. See id. at 352-53, 355, 361, 363, 380, 389, 395, 397, 403-04, 406, 412-15; 3 FOREIGN RELATIONS OF THE U.S. 1952-1954, at 827.

146. 2 FOREIGN RELATIONS OF THE U.S. 1951, at 390-91, 395-96, 403-04, 407-11, 414-15.

147. As explained in a later Departmental memorandum:

A Presidential ruling of this nature would establish a far-reaching precedent that the President has a right to rule on the effect of a Member's vote. To permit the President to make such a ruling subject only to rule 30 of the Council's Rules of Procedure would mean that the legality and effect of a Member's vote would 
it was recognized that if the Court entertained the request at all, it was unlikely to give the response desired by the Assembly majority, turning to the Court was variously justified as a tactic which would "buy time," and provide a better legal basis for any eventual Security Council action. ${ }^{148}$ Moreover, "it was better to litigate and lose than to lose only in a political arena"; and "even a negative decision by the Court would not do any particular harm." 149

The formulation of the request was the subject of a detailed memorandum of December 11, 1951, by James N. Hyde, Adviser to the U.S. Delegation. ${ }^{150}$ In it he set forth the advantages and disadvantages of an abstractly formulated request, related generally to the veto on admissions, as opposed to a request confined to the vote on Italy's application for admission. In addition, he presented two alternative drafts of Security Council resolutions to request a Court opinion. State Department instructions on the matter came shortly thereafter from Secretary of State Acheson. After firmly rejecting any "deal" tying Italian membership to simultaneous admission of Soviet satellites, and after stating his opposition to General Assembly action without a Security Council recommendation, Acheson turned his attention to the judicial option:

If [the] Sov[iet]s sh[ou]ld veto [Italy's membership] solely on nonCharter grounds, [the] Dep[artmen]t [is] prepared to support ref[feral of the question] to [the] ICJ to determine [the] effect [of the] Sov[iets'] negative vote. If [the] Sov[iet]s sh[ou]ld veto referring [the] question [to the] ICJ, [the] Dep[artmen]t believes [the] effects [of the] original Sov[iet] veto on Italy's admission sh[ou]ld be left undetermined, i.e., [the] Chairman sh[ou]ld make no ruling and call for no vote on this question. This will make it easier for [the] G[eneral] A[ssembly] later to ask [the] ICJ [for an] opinion [on] what [the] effect [of the] Sov[iet] veto in [the] S[ecurity] $\mathrm{C}$ [ouncil] is. This procedure at least offers some hope and will keep [the] issue alive for [the] time being. ${ }^{\text {is }}$

be left in the hands of the President and four other Members. The dangers of abuse of such a procedure cannot be minimized. For instance, on such a precedent the Soviet Chairman might rule that the vote of the Chinese National representative is illegal and it might not be possible to get seven votes to override him.

3 FOREIGN RELATIONS OF THE U.S. 1952-1954, at 828. Cf. id. at 665 (Ambassador Lodge's objections to an earlier suggestion by Acheson that the Court be asked to clarify the question of the applicability of the veto to the issue of Chinese credentials).

148. Telegram from U.S. Ambassador Warren R. Austin to Secretary of State Dean Acheson, 2 Foreign Relations OF THE U.S. 1951, at 404 (Dec. 6, 1951).

149. See id. at 391, 395-96 (statements of Mr. Fisher and Congressman Vorys of U.S. Delegation).

150. Id. at 407-09.

151. Id. at 410 . 
On that occasion, a vote was not taken in the Security Council, and the contingency plan was therefore not put into effect. ${ }^{152}$ Soon, however, the United States was faced with a new Italian-Peruvian initiative to evade the Security Council veto by having the Assembly characterize specific vetoes as illegal. Mr. Hyde was prompted to write a new memorandum, again suggesting possible recourse to the Court:

Any decision that the Dep[artmen]t takes on going along with action solely by the G[eneral] $A[$ ssembly] to admit a state to membership must necessarily be based on an analysis of how important the US regards the veto from the point of view of its security. ...

[I]t is clear that the Court has never passed on the question of when a negative vote is and when it is not a veto, and that question was left open in the 1950 opinion. Assuming there is strong sentiment in the G[eneral] A[ssembly] for the Belaunde theory, or in the $\mathrm{S}$ [ecurity] $\mathrm{C}$ [ouncil] for having a majority decide that a Soviet negative vote is illegal, it would clearly be better to try first of all to get the opinion of the Court in support of our position. Then, although we would be admitting members without the affirmative vote of the USSR in the S[ecurity] C[ouncil], we would have the support not only of the Assembly but also of the Court.

The State Dep[artmen]t would be willing to adopt this course, if we are faced with it. . . This would involve a request for an advisory opinion, preferably by the G[eneral] A[ssembly], the President of the S[ecurity] C[ouncil] making no ruling on the question of whether the vote on the Italian application does or does not constitute a recommendation. ${ }^{153}$

The need for such a step did not eventuate. However, the United States was soon called upon to react to the first formal proposal to solicit the Court's advice on the applicability of the veto to questions of admission.

3) The proposal, presented to the First Committee by five Central American states on January 24, 1952, would have had the Assembly request an advisory opinion on the following questions:

152. See id. at 411; U.N. SCOR, 6th Yr., 568th-569th mtgs. (Dec. 18-19, 1951).

153. Memorandum of December 20, 1951, 2 FOREIGN RELATIONS OF THE U.S. 1951, at 414-15. 
a. What are the rules or criteria to be followed in interpreting the result of votes in the Security Council on recommendations for the admission of new members?

b. Can the negative vote of one of the permanent members nullify a recommendation for admission which has obtained seven or more votes? ${ }^{154}$

A lengthy preamble referred, inter alia, to the fact that some Assembly delegations doubted that Article 27 procedure on "decisions"should be applied to Article 4, which spoke of "recommendations" by the Security Council and "decisions" by the General Assembly.

Before asking for State Department instructions, the U.S. Delegation canvassed the opinion of the Italian observer, Guidotti, who endorsed the idea at the time. ${ }^{155}$ The Delegation also consulted with the British and Belgian delegates, Vallat and Nisot, concerning the drafting of the proposal. As reported by Eleanor Roosevelt, Acting Chair of the U.S. Delegation, a "tactical question" was involved: Was it "better [to] take [the] language of sponsors or improve [the] language at [the] risk [of] associating ourselves with responsibility for [a] possible unfavorable answer from [the] court?" $M$. Nisot suggested narrowing the question to refer to the effect of a veto only in admission cases in which seven members of the Council voted for a state's admission and a permanent member voted against, "while recognizing that the state fulfills [the] conditions required" by Article 4, paragraph $1 .^{156}$

The response of Secretary of State Acheson, though halting, clearly tilted against the idea of a judicial solution. ${ }^{157}$ "While not enthusiastic re[garding] referral to ICJ," he stated, the State Department was "willing [to] support referral if [the] Ital[ian]s desire and if there is general sentiment in favor." However, he strongly criticized the formulation of the request.

If [the] matter [is] to be referred to [the] ICJ, [the] Dep[artmen]t believes [the] question submitted sh[ou]ld be calculated to assure [that the] ICJ will consider [the] question and increase [the] likelihood [of a] desirable decision.... [The] Preamble confuses [the] issues, and at least [the] first question calls for [a] general

154. U.N. Doc. A/C. $1 / 708$ (1952).

155. 2 FOREIGN RELATIONS OF THE U.S. 1951, at 445. Subsequently, the Italians had second thoughts, for fear that judicial recourse might act as a boomerang, leading to a firm pronouncement on the vetoability of applications for admission. Id. at 449.

156. Id. at $445-46$.

157. Telegram from U.S. Secretary of State Dean Acheson to Representative Austin, id. at 447-48 (Jan. 27, 1952). 
exposition on S[ecurity] C[ouncil] voting which is difficult and unfruitful to give, and which [the] ICJ may well refuse [to] undertake.

[The] Dep[artmen]t believes [that] if [the] question [is] submitted, it sh[ou]ld be along [the] lines of Nisot['s] proposal. . . . [The] Dep[artmen]t [is] prepared [to] accept [the] question as there drafted, although we have some difficulty with [the] word "recognizing". It is not clear whether an explicit statement that [the] applicant is qualified is contemplated, or whether recognition of qualification can be inferred indirectly, e.g., from Sov[iet] willingness [to] include Italy in [the] omnibus Res[olution].

The proposed exercise was clearly viewed as superfluous, at best:

[The] Dep[artmen]t has taken [the] position [that a] membership application is subject to veto. We are reluctant to go to [the] ICJ on [a] question the answer to which in our opinion is clear. However, if L[atin] A[merican] states and others insist, we w[ou]ld support [a] Res[olution] which submits two questions to [the] ICJ: (1) [the q]uestion contained in final Para[graph] of the L[atin] A[merican] proposal ... and (2) Nisot['s] question.

Further distancing himself from the suggestion, Mr. Acheson instructed the U.S. Delegation not to "take [the] lead" regarding "this aspect [of] membership question" and not to "cosponsor without prior consultation" with the Department. ${ }^{158}$

The sponsors of the draft resolution were persuaded to have consideration of their proposal deferred until the next (seventh) Assembly session. ${ }^{159}$ At that session, the U.S. Delegation informally discussed with several Latin American delegations the possibility of linking the proposed question on the veto to the Court's earlier opinion in the Admission case. As explained in a State Department position paper:

If a question were to be submitted to the Court, it should at least be calculated to increase the likelihood that the Court would consider the question and give a desirable decision. A question which linked the veto problem to the Court's 1948 opinion would seem to be the most logical alternative. For instance, the Court might be asked whether the Assembly can admit a state when a permanent member 
of the Security Council has proposed and voted for a proposal that the Council recommend the admission of the State as one of a group of states to be admitted simultaneously and yet voted against a proposal in the Security Council for a separate recommendation on the admission of the State, which proposal received seven or more affirmative votes and no negative vote from any other permanent member. ${ }^{160}$

Instead of pursuing this suggestion, the sponsors abandoned the idea of seeking a Court opinion and substituted a resolution urging the Assembly to attempt to resolve the admission problem. ${ }^{161}$ The Assembly decided, at its seventh session, to set up a special committee to study the admission question. ${ }^{162}$

4) Within the State Department, skepticism as to the advantage of judicial recourse continued to be expressed, both because the Court was unlikely to consider itself competent to deal with the issue and because if it did, it could not readily endorse the view desired by those seeking the Court's advice. ${ }^{163}$ Nevertheless, on occasion, State Department officials deemed the judicial option to be the one which, of all the other solutions under discussion, was the "least objectionable from our own standpoint." These officials thought that "we might have to resort to it in an effort to provide some new approach to the problem."164

The more objectionable solutions quickly became apparent during the deliberations of the Special Committee on Membership, where three different Latin American proposals were under consideration.

(a) Argentina resurrected the first part of its thesis, ${ }^{165}$ arguing that the Assembly might decide to admit a state even if the Security Council recommendation was "unfavorable."166 Although the thesis had been rejected by the Court in the Competence opinion, Argentina argued that the opinion was not binding and that the document of the travanx préparatoires upon which Argentina relied had not been dealt with by the Court.

160. 3 ForEIGN RELATIONS OF THE U.S. 1952-1954, at 952.

161. U.N. GAOR Ad Hoc Political Comm., 7th Sess., 42nd mtg. (Dec. 12, 1952), at 255. The new proposal was sponsored by four of the five co-sponsors of the earlier draft resolution to request the Court's opinion.

162. G.A. Res. 620A (VII) (Dec. 21, 1952). The study group idea accorded with the wishes of the U.S. Delegation, which sought a way of avoiding Assembly endorsement of either a Soviet package deal proposal or the Belaunde (Peru) plan. Acceptance of the latter would have allowed the Assembly to declare that certain applicants for membership had, in fact, received favorable recommendations from the Security Council. 3 FOREIGN RELATIONS OF THE U.S. 1952-1954, at 893-94. See also infra text accompanying note 168 .

163. See, e.g., id. at $828,833-34,836,868,920,947,952-53$.

164. Id. at 836 .

165. See supra notes $18-22$ and accompanying text.

166. U.N. Doc. A/AC.61/L.36 (1952). 
(b) A Salvadoran or Central American proposal would have deemed questions of admission to be procedural in nature, thus making the veto inapplicable and enabling the Assembly to proceed to admit certain applicants. $^{167}$

(c) A Peruvian proposal would have allowed the Assembly to determine that certain vetoes of applications for membership were illegitimate because they were contrary to the Admission opinion. The sponsor of the proposal, Mr. Belaunde, also implied that a "favorable" Security Council recommendation for admission might be deduced from multiple votes in the Council (e.g., a vote on another occasion for admission of an applicant as part of a package deal). ${ }^{168}$

In an internal legal memorandum, Mr. Leonard Meeker, AssistantLegal Adviser for U.N. Affairs, spelled out, in great detail, U.S. objections to each of these proposals. ${ }^{169}$ The Argentine proposal had been rejected by the Court's 1950 opinion which, though not technically binding, could not be lightly ignored; nor, in the U.S. view, did the Argentine thesis accord with a proper interpretation of the legislative history of Article $4 .{ }^{170}$ With respect to the Salvadoran proposal, it was not supported by the travaux préparatoires, despite their ambiguity; subsequent practice, including that of the General Assembly, contradicted it; and the Assembly was not free to interpret Article 27 in a manner "entirely repugnant to the interpretation which has consistently been given to that Article by the Council itself." 171 Finally, the Peruvian plan, which was certainly "ingenious," ran "counter to the usual practices of parliamentary bodies."172 In sum, the State Department concluded: "none of the Latin-American 'juridical' plans for breaking the membership impasse rests on a good legal foundation." 173

The U.S. representative on the Special Committee on Membership, therefore, was instructed to vote against all the Latin American initiatives, while expressing the "strong sympathy" of the United States with the motives of the sponsors. ${ }^{174}$ On the judicial option, he was to adopt a passive and skeptical stance:

167. U.N. Doc A/AC.61/L.31 (1952).

168. U.N. Doc. A/AC.61/L.30 (1952).

169. 3 FOREIGN RELATIONS OF THE U.S. 1952-1954, at 923-38.

170. Id. at 924-31. The United States had devoted a considerable part of its pleadings in the Competence case to a discussion of the travaux préparatoires. Id at 924 (citing Competence of the General Assembly For the Admission of a State to the United Nations, 1950 I.C.J. Pleadings 110-22). But the Court did not find it necessary to deal with the legislative history of the provision in question, and based its conclusions on the "natural and ordinary meaning of the words in question" and on the structure of the Charter. 1950 I.C.J. REP. 7-10.

171. 3 FOREIGN RELATIONS OF THE U.S. 1952-1954, at 931-36.

172. Id. at 937-38.

173. Id. at 938 .

174. Id. at 947 . 
If the Latin American countries wish to discuss the possibility of an advisory opinion from the International Court of Justice on the veto, a request for such an opinion should preferably be so framed as to link the question of the effect of a negative vote of a permanent member to the Court's opinion of 1948. However, the United States should not take the initiative in proposing this alternative or express optimism as to the results of recourse to the Court. ${ }^{175}$

None of the substantive proposals were endorsed, and the Court was not again embroiled in the controversy. Its previous 1948 pronouncement, however, seemed to present an obstacle to the emerging political solution to the impasse.

5) At the same time that Italy was urging innovative interpretations of the Charter, it also was attempting to persuade the United States to remove its firm opposition to Soviet proposals for a package deal, since such proposals seemed to offer the best, and perhaps only, hope for early Italian admission. Despite these pressures, the United States appeared to hold the line firmly against "omnibus resolutions" until mid-1952, insisting instead that each candidate be considered on its merits. ${ }^{176}$

Fidelity to the Charter and the spirit of the Court's opinion in the Admission case featured only tangentially in the reasons proffered by the United States for its adamant stand against compromise. ${ }^{17}$ More important considerations were: (1) the difficulty of selling to the American public a departure from the traditional U.S. posture against package deals and against the admission of Soviet satellites (especially Hungary); ${ }^{178}$ (2) the "serious effect in Korea" of admitting the "shadowy 'state" of the Mongolian People's Republic while excluding South Korea, which was then "fighting together with [the] UN [to] repel aggression against it"; ${ }^{179}$ and (3) the fear that with the Soviet satellites inside, the United States would be deprived of "future bargaining power re[garding] Japan and others we favor." 180 Nor was the

175. Id. at 947 ; see also id. at 952.

176. 2 FOREIGN RELATIONS OF THE U.S. 1951, at 351-52, 389, 410, 413-14, 417-19, 423, 431-32, $452-54$.

177. For passing references, see, e.g., id. at 351, 414.

178. See, especially, $i d$. at 431,453 . Apart from the still simmering dispute over human rights observance in Hungary, the American public was incensed over a recent aerial incident in which U.S. aviators had been detained by that state.

179. Id. at 431 .

180. Id.; see also id. at 453. Later, in an internal State Department Memorandum of May 13,1954 , U.S. objections to package deals were linked "principally" to the Chinese representation issue. 3 FOREIGN RELATTONS OF THE U.S. 1952-1954, at 1004. "Our agreement to admit Soviet-sponsored applicants despite their conduct," it was explained, "would make it harder 
United States persuaded by Italy that engaging in "benevolent abstention" on an omnibus resolution in the Security Council-on the assumption that only the Western candidates would proceed to muster the requisite two-thirds majority in the Assembly-would be a riskless endeavor. Given the strong sentiment for universality in the General Assembly, it was likely that some or all of the Soviet candidates would be admitted sooner or later. ${ }^{181}$ Nevertheless, the United States agreed that if the Soviet omnibus resolution obtained seven votes in the Security Council, the United States would abstain rather than cast a veto. ${ }^{182}$ However, since only six votes were cast in favor, the United States voted against and proceeded to attempt to assuage Italy's keen disappointment. ${ }^{183}$

By mid-1952, the State Department was clearly veering toward an abandonment of its previous policy on package deals - mainly in order to insure Italian and Japanese admission. It began concentrating on the new task of mobilizing the public opinion necessary to support this change in direction. ${ }^{184}$ The ultimate result was the package deal of December 1955, which included Italy and the European satellites. ${ }^{185}$ The words of Judge Krylov in his dissenting opinion in the 1948 Admission case proved to be prophetic:

In the present case, it may be asked whether the political organs of the United Nations, acting under conditions which cannot even be foreseen at the present time, might not one day depart from the precepts of the Court's opinion. ${ }^{186}$

In sum, it may be said that following the Competence opinion, State Department thinking on the role of judicial pronouncements as an aid in breaking the continuing admission deadlock was fairly realistic. With the veto and double veto under steady assault, especially by the Latin American states, the United States sometimes retreated briefly to contemplate the judicial option as a diversionary tactic. Even a "negative decision" by the Court-negative, presumably, from the standpoint of the Assembly majority rather than, necessarily, the United States-could do no harm and might even be

for us to keep out the Chinese Communists." Id.

181. See 2 FOREIGN RELATIONS OF THE U.S. 1951, at 389, 417-19, 423.

182. Id. at 431.

183. Id. at 452-54. For the proceedings of the Security Council, see U.N. SCOR, 7th Yr., 573rd mtg. (Feb. 6, 1952), at 3-39.

184. 3 FOREIGN RELATONS OF THE U.S. 1952-1954, at 836-37, 918-23. But see id. at 1004 (cited supra note 180), regarding State Department objections to package deals.

185. G.A. Res. 995 (X) (Dec. 14, 1955). Japan was admitted a year later, and Mongolia only in 1961.

186. 1948 I.C.J. REP. 109. 
advantageous and "buy time. ${ }^{\text {"187 }}$ Ultimately, the time was used neither for more judicial recourse nor for operating within the perimeters set by previous judicial pronouncements, but for devising the requisite political compromises.

\section{The Cuban Question}

During the 1962 Security Council debates on the Cuban question, observers were treated to an unusual spectacle, a harbinger of trends which would become more manifest over two decades later. The Soviet Union and its Latin American protégé, Cuba, assumed the mantle of proponents of greater recourse to the Court and successfully maneuvered the United States and its allies into the uncomfortable defensive position of spurning a U.N. member's urgent plea for judicial clarification of its grievances.

Cuba's grievances stemmed from the series of resolutions adopted by the Organization of American States ("OAS") at its 1962 Punta del Este meeting, resolutions which, inter alia, excluded Cuba from participation in the interAmerican system, and suspended certain categories of trade with Cuba. ${ }^{188}$ Thwarted, at first, in its attempt to get the matter inscribed in the Security Council agenda, ${ }^{189}$ Cuba changed its tactics, imparting to its complaint a legal aspect.

The OAS measures, Cuba maintained, constituted illegal "enforcement action," since they had not been authorized by the Security Council, as required by Article 53 of the U.N. Charter. Furthermore, Article 52 obligated regional organizations to observe the "Purposes and Principles of the United Nations;" and according to Cuba, expulsion of a state on the basis of its social system conflicted with such central Charter principles as self-determination, nonintervention, and the tenet of universality embodied in Article 4. In addition, the OAS, it was charged, had acted contrary to its own Charter and to the Rio Treaty. Cuba translated its arguments into a draft resolution containing seven, decidedly loaded questions and requested that the Security Council convene for the purpose of referring these "specific legal questions" to the Court for an advisory opinion. ${ }^{190}$ The Court would be urged to give the

187. 2 FOREIGN RELATIONS OF THE U.S. 1951, at 395-96, 404.

188. See U.N. Doc. S/5075 (1962).

189. U.N. SCOR, 17th Yr., 991st mtg. (Feb. 27, 1962).

190. For the Cuban proposal, see U.N. Docs. S/5086 \& S/5095 (1962). See also, for Cuba's elaboration of its case, U.N. SCOR, 17th Yr., 992nd mtg. (Mar. 14, 1962); id., 994th mtg. (Mar. 16, 1962), at 1-5; id., 997th mtg. (Mar. 22, 1962), at 7-16.

Questions 3 and 7 of the Cuban draft resolution were the most important. Question 3 asked:

Can the expression 'enforcement action' in Article 53 of the United Nations Charter 
matter priority; and pending receipt of the opinion, the Security Council would adopt a "provisional measure" under Article 40 calling on the OAS to suspend its anti-Cuban resolutions.

For Cuba and its Soviet patron, the new tactic appeared to entail several benefits. Ideally, the Cuban proposal, if adopted, would grant Cuba a welcome temporary reprieve from the harsh OAS measures. At a minimum, the Security Council would be induced to at least discuss the Cuban complaints-since it could hardly deny a state a hearing on a "legal" request of this nature. Beyond that, the United States and the West would be compelled to concede, implicitly, that they feared an advisory opinion and perhaps doubted the legality of the OAS actions.

Cuba succeeded in obtaining the desired Security Council platform and proceeded to deliver the opening salvo in the long propaganda battle that ensued. ${ }^{191}$ Interspersed with arguments on the legal issues were charges that the United States was planning renewed armed intervention against Cuba. The legal questions which Cuba wished to have referred to the Court were "very important for Cuba and for the independence of all Member States which want to defend their sovereignty through the rule of international law but which, should international law not provide them with sufficient protection, would ... defend their independence and international legal principles, if necessary with the blood of their own sons." 192 "What organ of greater authority than the Court," the Cuban representative asked, "could be requested to give this verdict" regarding the legal issues raised? ? $^{193}$ "What argument can be used against requesting such an opinion, if not a lack of faith in the legality of the Punta del Este agreements?"194 If an opinion "is prevented by the use of a mechanical majority in the Council," he asserted, "this will be solely because of a desire to prevent the verdict of the International Court of Justice

be considered to include the measures provided for in Article 41 of the United Nations Charter? Is the list of these measures in Article 41 exhaustive?

And the final question was:

In the light of the replies to the foregoing questions are, or are not, the resolutions adopted at Punta del Este ... relating to the expulsion of a State member of the regional agency because of its social system and the taking of other enforcement action against it, without the authorization of the Security Council, consistent with the provisions of the United Nations Charter, the Charter of the Organization of American States and the Treaty of Rio?

191. The matter was discussed at Security Council meetings 992-998, March 14-23, 1962. This was the only instance in which the Security Council was specially convened for the purpose of deciding whether to request an advisory opinion. Normally, proposals for requesting opinions arise in connection with issues already under discussion.

192. U.N. SCOR, 17th Yr., 992nd mtg. (Mar. 14, 1962), at 26.

193. II. at 28 .

194. Id. at 26. 
going against the unlawful activities of the regional agency." 195 "We, who know that international law is on our side," he continued, "do not fear decisions of the International Court." 196

Mr. Morozov, the Soviet representative, repeated and supplemented the Cuban arguments. ${ }^{197}$ The Court, he said, was considered by "most members of our Organization-though not, apparently, by the United States- . . . competent to give an impartial and objective reply on the legal points ... "198 Such "an objective answer . . . will ... make it impossible for the United States ... and a number of other States which follow it, to continue to use the smoke-screen behind which they are now making political, economic and military preparations for a new attack on Cuba." 199 In the meantime, the Security Council had "a right and a duty to suspend implementation" of the Punta del Este resolutions. ${ }^{200}$ But the period involved need not be long. "Unless some improper pressure is put on the Court, its opinion can and must be forthcoming in the shortest possible time."201

The United States was not alone in perceiving the Soviet-Cuban initiative as a thinly veiled attempt to render the OAS and other regional organizations impotent by subjecting them to the Soviet veto. There was no justification, U.S. representative Adlai Stevenson urged, for falling into the new trap, just because of its present "legal" disguise. The proposal remained "political," and the motives of its sponsors, clearly suspect and dangerous.

The representative of Cuba, has, regrettably, not presented his request for a judicial opinion in a very judicial manner. Rather, by the tone and substance of his speech . . . it is clear that he is again arguing about a political dispute.... This time, the attack is against the Organization of American States. But it is clearly aimed at all regional organizations: it is an attempt to subject the activities of all regional organizations to the Soviet veto in the Security Council. ... The Cuban letter is camouflaged with legalisms, but the issues it raises are 100 per cent political. ${ }^{202}$

The United States Government has repeatedly made clear that it favours increased recourse to the International Court of Justice. But it does not favour use of the Court for cold war political

195. Id. at 28.

196. Id. at 26.

197. Id., 993rd mtg. (Mar. 15, 1962), at 2-13.

198. Id. at 9.

199. Id. at 8 .

200. Id. at 12 .

201. Id. at 13.

202. Id. at 14 . 
purposes foreign to the Charter and the Statute of the Court. It is significant, in this connexion, that the Soviet representative, whose Government is consistently hostile to the use of the Court for the settlement of genuine legal disputes between States, and has deprecated the Court's advisory jurisdiction, should so enthusiastically favour submission to the Court of the rhetorical and self-serving questions which have been conjured up by the Cuban representative. ${ }^{203}$

[T] he Cuban complaint is politically, and not legally, motivated. The International Court of Justice should not be brought into the cold war or into the jungle of Communist propaganda. ${ }^{204}$

Apart from its political taint, the Cuban request should also "be dismissed for lack of substantiality, Stevenson argued."205 The measures complained of were undoubtedly within the exclusive jurisdiction of the OAS. Clearly, a regional agency had the exclusive right to determine its own membership. Moreover, the economic measures adopted were not in the nature of "enforcement measures"-that term (as the Council had already determined in connection with the Dominican Republic question ${ }^{206}$ ) being reserved for action solely within the Security Council's competence (i.e., the use of force). It therefore was entirely "pointless" to refer to the Court decisions which were so noncontroversial. ${ }^{207}$

In response to the foregoing objections, the Cuban and Soviet representatives in effect raided the arsenal from which the United States and the Western states had traditionally drawn their arguments in favor of greater recourse to the Court's advisory function. Thus, Mr. Morozov, in the best

203. Id. at 24.

204. Id., 994th mtg. (Mar. 16, 1962), at 7. For other arguments emphasizing the political nature of the Cuban request, see the statements of the United Kingdom, id., 995th mtg. (Mar. 20, 1962), at 2-4; of France, id. at 10-12; and of Ireland, id., 996th mtg. (Mar. 21, 1962), at 12-13. See also the Irish argument against "unwarrantably invading the autonomy which the Organization of American States is justifiably entitled to enjoy," id. at 11-12; and the comments of Chile, id., 994th mtg. (Mar. 16, 1962), at 14-15.

205. Id., 993rd mtg. (Mar. 15, 1962), at 24.

206. See id., 15th Yr., 893rd-895th mtgs. (Sept. 8-9, 1960). But cf. Inis L. Claude, Jr., The OAS, the UN, and the United States, InT'L ConCILIATION, Mar. 1964, No. 547, at 48-53. (to the effect that the "Dominican precedent" was by no means as unequivocal as it was later construed to be).

207. U.N. SCOR, 17th Yr., 993rd mtg. (Mar. 15, 1962), at 15-24. See also the statements of the United Kingdom, id., 995th mtg. (Mar. 20, 1962), at 4-6; China, id. at 6-9; Ireland, id., 996th mtg. (Mar. 21, 1962), at 12-13; and Venezuela, id., 997th mtg. (Mar. 22, 1962), at 1-7. 
Western tradition, declared:

[I]f we were to agree at any juncture with the position of denying the importance of the principles of international law for the solution of political problems in the Security Council-which is the logical result of the stand taken by the United States representative and certain others in the Council-we would be denying that legal problems were of any significance in decisions on political questions in the Security Council. But we cannot break this organic link. It would be tantamount to admitting that anarchy, chaos and arbitrary action reigned in the United Nations. ${ }^{208}$

And the Cuban representative pleaded, in like vein:

In such a serious question as the scope of the Articles of the Charter that relate to the competence of this Council and are linked to such extraordinary measures as the expulsion of a Member State from a regional organization and the imposition of coercive measures on that State without the authorization of this Council, surely the least that can be granted is the right of that Member State, and of the international juridical community, to a clear and final ruling, made by those who are qualified and have the knowledge and mission to do so, on whether or not the international norm has been complied with? How can the effectiveness of treaties in so important and serious a matter be guaranteed? ${ }^{209}$

Addressing himself at great length to the "political question" objection, the Cuban representative launched a vigorous counter-attack. First, he argued, the Court itself should be allowed to rule on the "judicial" nature of the questions. ${ }^{210}$ Second, acceptance of the argument that the Cuban questions were political "would render Article 96 of the ... Charter virtually inoperative: a State concerned in a case would only have to assert that political questions were involved for the ... Court ... to be precluded from giving an opinion." In the present case, Cuba's legal questions were "being withheld from the Court by politicians, using political arguments, on the pretext that such questions have a concealed political purpose." In any event, however, the motivation behind the request was irrelevant.

208. Id., 998th mtg. (Mar. 23, 1962), at 8.

209. Id., 994th mtg. (Mar. 16, 1962), at 4-5.

210. Id. at 4. 
We seem to have heard some member of the Council object to the questions we raised on the ground that they are not 'purely legal' and are not prompted by a desire for 'legal knowledge,' as if the reasons motivating a State in requesting an advisory opinion also had to be legal and as if the International Court of Justice, that modern academy of international law, existed solely to dispel the scientific doubts of those who bring before it legal questions which are 'chemically pure'; as if every one of us, every time we came to this Council or engaged in any activity in this house, were not doing so in response to political necessity. If the questions put to the Court are framed in legal terms, objectively legal terms, that should be sufficient, and we should refrain from any consideration of their motivation. ${ }^{211}$

The true reason for opposition to the Cuban proposals, the Cuban representative repeatedly emphasized, was fear of an adverse verdict:

If the United States representative is so sure of the rightness of his position, why is he against requesting the . . Court . . . for an opinion? And if not . . . of what value is his statement that his Government favours increased recourse to the Court? $?^{212}$

[W] hy should we not let the Court answer the legal issues we raise? Is it because we have doubts about the Court? Or do we not want an advisory opinion because the legal arguments are on the side of a small Member State in the war which another powerful Member State has launched against it? ${ }^{213}$

Clearly, Cuba was playing its propaganda advantage to the hilt.

Outside of the Soviet bloc, the Cuban proposal found its only real support in Ghana. ${ }^{214}$ The Ghanaian representative conceded that some of the Cuban questions were either "political" or not relevant to the main juridical issue involved. The key issue, as far as he was concerned, was whether the Punta

211. Id., 997th mtg. (Mar. 22, 1962), at 12.

212. Id., 994th mtg. (Mar. 16, 1962), at 2.

213. Id., 997th mtg. (Mar. 22, 1962), at 12.

214. The U.A.R., which might normally have been expected to lend more enthusiastic support to the Cuban proposal, was apparently caught up in a dilemma because of the implications of the Cuban request for regional organizations generally, including, therefore, the Arab League. Particularly objectionable to the U.A.R. was the Cuban theory that the regional agency should be a "microcosm" of the United Nations without the right to exclude members at will. Id., 996th mtg. (Mar. 21, 1962), at 7-9. The U.A.R. voted for referring question 3 of the Cuban request to the Court, but it abstained on the other questions. 
del Este resolutions did, in fact, constitute "enforcement action" within the meaning of Article 53 of the U.N. Charter (question 3 of the Cuban proposal). On this point, doctrine was divided, and, despite the so-called "Dominican precedent," reasonable doubt remained among Council members. The existence of these doubts constituted the strongest argument in favor of the Cuban request.

For, if juridical proprieties were to be abandoned in the formulation and execution of such important political decisions as those complained of, the very principles of international law and the basis of the Charter would be undermined; and those who would suffer most from such a development would be the small, weak States whose only recourse is the rule of international law. ${ }^{215}$

The Ghanaian representative therefore appealed to the Security Council to grant the request which Cuba, "as an aggrieved party," had presented. Although "bedeviled with political arguments," that request was-at least insofar as the interpretation of "enforcement action" was concerned-a "specific legal request" which merited the Council's endorsement. ${ }^{216}$

On Ghana's motion, and with Cuban consent, a separate vote was taken on question $3 .^{217}$ That paragraph was defeated by a vote of 7 to $4 .^{218}$ The remainder of the Cuban draft was defeated by an even wider margin. ${ }^{219}$

Whether or not Cuba and the Soviet Union reaped the expected propaganda dividend from the exercise in the Security Council, the United States and its allies were clearly placed in an embarrassing position. They now were denying to a Soviet bloc member what they had, on other occasions, standardly asserted to be a state's prerogative-namely, to have a judicial, and not merely a political, forum determine its rights. At least implicitly, they were conceding that they feared an adverse verdict-which, indeed, they did. They clearly were anxious to avoid judicial interpretation of Article 53 of the Charter. After all, it was precisely because of the Cold War that this provision had been evaded, even with respect to the use of armed force. The West had succeeded in having its interpretation prevail in the Security Council, but, as noted by Inis Claude, there could be "no assurance that the Court would similarly place general

215. Id. at 18 .

216. Id. at 19. For the entire Ghanaian argument, see id. at 13-19.

217. Id., 998th mtg. (Mar. 23, 1962), at 16-17, 21.

218. Id. at 21. Voting in favor were Ghana, Rumania, the Soviet Union, and the U.A.R. Id.

219. The vote was 2 for, 7 against, with 1 abstention. The U.A.R. abstained, and Ghana did not participate in the vote. After the vote on question 3, the Soviet and Cuban representatives, for obvious reasons, did not wish to have the remainder of the proposal voted on. The President's ruling to put the rest of the draft to a vote was upheld by a vote of 7 to 2 , with 2 abstentions (the U.A.R. and Ghana). 
political considerations above textual analysis of the Charter."220 Neither the United States nor any of its allies was prepared to allow the Soviet Union and Cuba to refoist upon the Western regional organizations the shackles of the veto from which they had effectively extricated themselves.

With the changing composition of the U.N. and the Court, U.S. distrust of the Court and, correspondingly, the confidence of the Soviet and Third World states, were to grow. What Cuba failed to do in 1962, Nicaragua succeeded in accomplishing in 1984-86. It obtained (amid loud U.S. protests) judicial clarification of a dispute between a Soviet-aligned Latin American state and the colossus of the North. Thus, the reversal of roles, adumbrated in 1962 , became complete.

\section{CONCLUSIONS}

In the early years of the Cold War, when the United Nations and the Court were arenas hospitable to U.S. interests, the solicitation of judicial assistance in East-West controversies appeared, on occasion, a tempting prospect. Like the Uniting for Peace Resolution, recourse to the Court's advisory function offered a way of overcoming Soviet "obstructionism," obtaining some action, or at least the appearance of action, and scoring propaganda points.

Contrary to widely held assumptions, the record reveals no consistent U.S. inclination to exploit the Court maximally and indiscriminately for these purposes. Most often, U.S. policymakers were guided by pragmatic calculations of costs and benefits, rather than a crusading spirit or reflexive, knee-jerk reactions. Thus, in determining their attitude regarding reference to the Court and the terms of that reference, they took into account such matters as: the potential exposure of the United States itself to direct Assembly investigation of human rights issues in the future (in the Peace Treaties case); the negative implications for long-term U.S. interests of weakening the veto power in the Security Council (in the Competence case and its aftermath); the undesirability of having a judicial straitjacket placed around General Assembly efforts to develop the emergent international law of human rights (in the Peace Treaties case); the possibility that an alternative procedure would yield a better propaganda dividend (as in the matter of exit visas for Soviet wives); and the need to avoid, at all costs, the risk of introducing a Soviet veto over the activities of regional organizations (in the Cuban case).

The pragmatic approach was not, however, much in evidence in relation to the Expenses request. Short-term pique and anti-Soviet fervor prevailed over long-term interest. The possible boomerang effect of securing the desired 
Court opinion was not appreciated until several years later. By announcing the "Goldberg Reservation" in 1965, ${ }^{221}$ the United States was implicitly conceding that its influence in the General Assembly was waning and might, indeed, be more greatly curtailed in the years to come. From the other side of the Iron Curtain, the Soviet Union, by backing the Cuban appeal for an advisory opinion three years earlier, was evincing a corresponding awareness that in the evolving U.N. system, the Court should no longer be seen as a hostile forum.

Clearly, the demise of the Cold War has not transformed the U.N. organs-including the Court-into fora either instinctively friendly or reflexively hostile to U.S. interests. Nor, even today, is a judicial solution to international problems automatically to be preferred in all instances. "Litigation," as Shabtai Rosenne aptly observed, "is but a phase in the unfolding of a political drama." 222 The likely effects of litigation (whether contentious or advisory) on the immediate problem at hand, the longer-term political interests at stake, the emergence of international norms, and the stature of the International Court-are still important in any realistic cost-benefit assessment. In this respect, the generally pragmatic American approach to judicial consultations, which underlay the U.S.-ICJ nexus during the Cold War, remains relevant today. 